\title{
International Evidence on GFC-robust Forecasts for Risk Management under the Basel Accord*
}

\author{
Michael McAleer \\ Econometric Institute \\ Erasmus School of Economics \\ Erasmus University Rotterdam \\ and \\ Tinbergen Institute \\ The Netherlands \\ and \\ Institute of Economic Research \\ Kyoto University \\ Japan \\ Juan-Ángel Jiménez-Martín \\ Department of Quantitative Economics \\ Complutense University of Madrid \\ Teodosio Pérez-Amaral \\ Department of Quantitative Economics \\ Complutense University of Madrid
}

Revised: January 2011

* The authors are most grateful for the helpful comments and suggestions of participants at the Kansai Econometrics Conference, Osaka, Japan, January 2011. For financial support, the first author wishes to thank the Australian Research Council, National Science Council, Taiwan, and the Japan Society for the Promotion of Science, and the second and third authors acknowledge the financial support of the Ministerio de Ciencia y Tecnología and Comunidad de Madrid, Spain. 


\begin{abstract}
A risk management strategy that is designed to be robust to the Global Financial Crisis (GFC), in the sense of selecting a Value-at-Risk (VaR) forecast that combines the forecasts of different VaR models, was proposed in McAleer et al. (2010c). The robust forecast is based on the median of the point VaR forecasts of a set of conditional volatility models. Such a risk management strategy is robust to the GFC in the sense that, while maintaining the same risk management strategy before, during and after a financial crisis, it will lead to comparatively low daily capital charges and violation penalties for the entire period. This paper presents evidence to support the claim that the median point forecast of VaR is generally GFC-robust. We investigate the performance of a variety of single and combined VaR forecasts in terms of daily capital requirements and violation penalties under the Basel II Accord, as well as other criteria. In the empirical analysis, we choose several major indexes, namely French CAC, German DAX, US Dow Jones, UK FTSE100, Hong Kong Hang Seng, Spanish Ibex35, Japanese Nikkei, Swiss SMI and US S\&P500. The GARCH, EGARCH, GJR and Riskmetrics models, as well as several other strategies, are used in the comparison. Backtesting is performed on each of these indexes using the Basel II Accord regulations for 2008-10 to examine the performance of the Median strategy in terms of the number of violations and daily capital charges, among other criteria. The Median is shown to be a profitable and safe strategy for risk management, both in calm and turbulent periods, as it provides a reasonable number of violations and daily capital charges. The Median also performs well when both total losses and the asymmetric linear tick loss function are considered
\end{abstract}

Key words and phrases: Median strategy, Value-at-Risk (VaR), daily capital charges, robust forecasts, violation penalties, optimizing strategy, aggressive risk management, conservative risk management, Basel II Accord, global financial crisis (GFC).

JEL Classifications: G32, G11, G17, C53, C22. 


\section{Introduction}

The Global Financial Crisis (GFC) of 2008-09 has left an indelible mark on economic and financial structures worldwide, and caused a generation of investors to wonder how things could have become so bad (see, for example, Borio (2008)). There have been many questions asked about whether appropriate regulations were in place, especially in the USA, to ensure the appropriate monitoring and encouragement of (possibly excessive) risk taking.

The Basel II Accord ${ }^{1}$ was designed to monitor and encourage sensible risk taking, using appropriate models of risk to calculate Value-at-Risk (VaR) and subsequent daily capital charges. VaR is defined as an estimate of the probability and size of the potential loss to be expected over a given period, and is now a standard tool in risk management. It has become especially important following the 1995 amendment to the Basel Accord, whereby banks and other Authorized Deposit-taking Institutions (ADIs) were permitted (and encouraged) to use internal models to forecast daily VaR (see Jorion (2000) for a detailed discussion). The last decade has witnessed a growing academic and professional literature comparing alternative modelling approaches to determine how to measure and forecast $\mathrm{VaR}$, especially for large to very large portfolios of financial assets.

The amendment to the initial Basel Accord was designed to encourage and reward institutions with superior risk management systems. A back-testing procedure, whereby actual returns are compared with the corresponding $\mathrm{VaR}$ forecasts, was introduced to assess the quality of the internal models used by ADIs. In cases where internal models led to a greater number of violations than could reasonably be expected, given the

\footnotetext{
${ }^{1}$ When the Basel I Accord was concluded in 1988, no capital requirements were defined for market risk. However, regulators soon recognized the risks to a banking system if insufficient capital were held to absorb the large sudden losses from huge exposures in capital markets. During the mid-90's, proposals were tabled for an amendment to the 1988 Accord, requiring additional capital over and above the minimum required for credit risk. Finally, a market risk capital adequacy framework was adopted in 1995 for implementation in 1998. The 1995 Basel I Accord amendment provides a menu of approaches for determining market risk capital requirements, ranging from a simple to intermediate and advanced approaches. Under the advanced approach (that is, the internal model approach), banks are allowed to calculate the capital requirement for market risk using their internal models. The use of internal models was introduced in 1998 in the European Union. The 26 June 2004 Basel II framework, implemented in many countries in 2008 (though not yet in the USA), enhanced the requirements for market risk management by including, for example, oversight rules, disclosure, management of counterparty risk in trading portfolios.
} 
confidence level, the ADI is required to hold a higher level of capital (see Table 1 for the penalties imposed under the Basel II Accord). Penalties imposed on ADIs affect profitability directly through higher capital charges, and indirectly through the imposition of a more stringent external model to forecast $\mathrm{VaR}^{2}{ }^{2}$ This is one reason why financial managers may prefer risk management strategies that are passive and conservative rather than active and aggressive (this issue will be discussed in greater detail below).

Excessive conservatism can have a negative impact on the profitability of ADIs as higher capital charges are subsequently required. Therefore, ADIs should perhaps consider a strategy that allows an endogenous decision as to how often ADIs should violate, and hence incur violation penalties, in any financial year (for further details, see McAleer and da Veiga (2008a, 2008b), McAleer (2009), Caporin and McAleer (2010a), and McAleer et al. (2010a, 2010b)).

Furthermore, ADIs need not restrict themselves to using only a single risk model. McAleer et al. (2010a) propose a risk management strategy that consists of choosing from among different combinations of alternative risk models to forecast VaR. They discuss a combination of forecasts that may be characterized as an aggressive strategy, and another that may be regarded as a conservative strategy. ${ }^{3}$

Following such an approach, McAleer et al. (2010c) suggest using a combination of $\mathrm{VaR}$ forecasts to obtain a crisis robust risk management strategy. That paper defines a crisis robust strategy as an optimal risk management strategy that remains unchanged regardless of whether it is used before, during or after a significant financial crisis. Parametric methods for forecasting VaR are typically fitted to historical returns, assuming specific conditional distributions of returns, such as Gaussian, Student-t, or Generalized Normal distributions. The VaR forecast depends on the parametric model and the conditional distribution, and can be heavily affected by a few large

\footnotetext{
${ }^{2}$ In the 1995 amendment (p. 16), a similar capital requirement system was recommended, but the specific penalties were left to each national supervisor. We consider that the penalty structure contained in Table 1 of this paper belongs only to Basel II, and was not part of Basel I or its 1995 amendment.

${ }^{3}$ This is a novel possibility. Technically, a combination of forecast models is also a forecast model. In principle, the adoption of a combination of forecast models by a bank is not forbidden by the Basel Accords, although it is subject to regulatory approval.
} 
observations. Some models provide many violations, but can also lead to low daily capital charges. Additionally, these results can change drastically from tranquil to turbulent periods. Using the S\&P 500 index, the authors provided evidence that the Median of the point VaR forecasts of a set of univariate conditional volatility models is a risk management strategy that is superior to strategies based on single and composite model alternatives.

In this paper we present cross-country evidence to support the claim that the Median point forecast of $\mathrm{VaR}$ is generally GFC-robust. We choose several major indexes, namely French CAC, German DAX, US Dow Jones, UK FTSE100, Hong Kong Hang Seng, Spanish Ibex35, Japanese Nikkei, Swiss SMI and US S\&P 500. For each index, as in McAleer et al. (2010c), we estimate 10 univariate conditional volatility models to forecast VaR, assuming different returns distributions (specifically, Gaussian, Student-t and Generalized Normal). Additionally, we present strategies based on combinations of standard VaR model forecasts, namely: lowerbound, upperbound (as defined in McAleer et al. (2010a)), average, and Median.

A total of 14 models and combinations of models are compared over three different time periods to investigate whether we can find a risk management strategy that is invariant over time (namely, a strategy that is crisis-robust). We find that the Median of the point $\mathrm{VaR}$ forecasts of a set of forecast models is a risk management strategy that settles in the green zone before the crisis and in the yellow zone during and after the crisis. While some competing strategies perform better before the crisis, they tend to have too many violations during and after the crisis. The analysis of well-known complementary criteria, such as the accumulated losses and asymmetric loss tick functions, reinforce these conclusions.

The remainder of the paper is organized as follows. In Section 2 we present the main ideas of the Basel II Accord Amendment as it relates to forecasting VaR and daily capital charges. Section 3 reviews some of the most well-known models of conditional volatility that are used to forecast VaR. In Section 4 the data used for estimation and forecasting are presented. Section 5 analyses the VaR forecasts before, during and after the 2008-09 GFC. Section 6 presents some conclusions. 


\section{Forecasting Value-at-Risk and Daily Capital Charges}

The Basel II Accord stipulates that daily capital charges (DCC) must be set at the higher of the previous day's VaR or the average VaR over the last 60 business days, multiplied by a factor $(3+k)$ for a violation penalty, wherein a violation involves the actual negative returns exceeding the $\mathrm{VaR}$ forecast negative returns for a given day: ${ }^{4}$

$$
\mathrm{DCC}_{\mathrm{t}}=\sup \left\{-(3+\mathrm{k}) \overline{\mathrm{VaR}}_{60},-\mathrm{VaR}_{\mathrm{t}-1}\right\}
$$

where

$D C C_{t}=$ daily capital charges, which is the higher of $-(3+\mathrm{k}) \overline{\mathrm{VaR}}_{60}$ and $-\mathrm{VaR}_{\mathrm{t}-1}$,

$V a R_{t}=$ Value-at-Risk for day $t$,

$\operatorname{VaR}_{t}=\hat{Y}_{t}-z_{t} \cdot \hat{\sigma}_{t}$

$\overline{\mathrm{VaR}}_{60}=$ mean $\mathrm{VaR}$ over the previous 60 working days,

$\hat{Y}_{t}=$ estimated return at time $\mathrm{t}$,

$z_{t}=1 \%$ critical value of the distribution of returns at time $t$,

$\hat{\sigma}_{t}=$ estimated risk (or square root of volatility) at time $\mathrm{t}$,

$0 \leq \mathrm{k} \leq 1$ is the Basel II violation penalty (see Table 1 ).

\section{[Insert Table 1 here]}

The multiplication factor ${ }^{5}$ (or penalty), $k$, depends on the central authority's assessment of the ADI's risk management practices and the results of a simple backtest. It is

\footnotetext{
${ }^{4}$ Our aim is to investigate the likely performance of the Basel II regulations. In this section, we carry out our analysis applying the Basel II formulae to a period that includes the 2008-09 GFC, during which the Basel II Accord regulations were not fully implemented.

${ }^{5}$ The formula in equation (1) is contained in the 1995 amendment to Basel I, while Table 1 appears for the first time in the Basel II Accord in 2004.
} 
determined by the number of times actual losses exceed a particular day's VaR forecast (Basel Committee on Banking Supervision (1996, 2006)). The minimum multiplication factor of 3 is intended to compensate for various errors that can arise in model implementation, such as simplifying assumptions, analytical approximations, small sample biases and numerical errors that tend to reduce the true risk coverage of the model (see Stahl (1997)). Increases in the multiplication factor are designed to increase the confidence level that is implied by the observed number of violations to the 99 per cent confidence level, as required by regulators (for a detailed discussion of VaR, as well as exogenous and endogenous violations, see McAleer (2009), Jiménez-Martin et al. (2009), and McAleer et al. (2010a)).

In calculating the number of violations, ADIs are required to compare the forecasts of VaR with realised profit and loss figures for the previous 250 trading days. In 1995, the 1988 Basel Accord (Basel Committee on Banking Supervision (1988)) was amended to allow ADIs to use internal models to determine their VaR thresholds (Basel Committee on Banking Supervision (1995)). However, ADIs that propose using internal models are required to demonstrate that their models are sound. Movement from the green zone to the red zone arises through an excessive number of violations. Although this will lead to a higher value of $k$, and hence a higher penalty, violations will also tend to be associated with lower daily capital charges. ${ }^{6}$

Value-at-Risk refers to the lower bound of a confidence interval for a (conditional) mean, that is, a "worst case scenario on a typical day". If interest lies in modelling the random variable, $Y_{t}$, it could be decomposed as follows:

$$
Y_{t}=E\left(Y_{t} \mid F_{t-1}\right)+\varepsilon_{t}
$$

This decomposition states that $Y_{t}$ comprises a predictable component, $E\left(Y_{t} \mid F_{t-1}\right)$, which is the conditional mean, and a random component, $\varepsilon_{t}$. The variability of $Y_{t}$, and hence

\footnotetext{
${ }^{6}$ The number of violations in a given period is an important (though not the only) guide for regulators to approve a given VaR model.
} 
its distribution, is determined by the variability of $\varepsilon_{t}$. If it is assumed that $\varepsilon_{t}$ follows a conditional distribution, such that:

$$
\varepsilon_{t} \sim D\left(\mu_{t}, \sigma_{t}^{2}\right)
$$

where $\mu_{t}$ and $\sigma_{t}$ are the conditional mean and standard deviation of $\varepsilon_{t}$, respectively, these can be estimated using a variety of parametric, semi-parametric or non-parametric methods.

The VaR threshold for $Y_{t}$ can be calculated as:

$$
\operatorname{VaR}_{t}=E\left(Y_{t} \mid F_{t-1}\right)-\alpha \sigma_{t}
$$

where $\alpha$ is the critical value from the distribution of $\varepsilon_{t}$ to obtain the appropriate confidence level. It is possible for $\sigma_{t}$ to be replaced by alternative estimates of the conditional standard deviation in order to obtain an appropriate VaR (for useful reviews of theoretical results for conditional volatility models, see Li et al. (2002) and McAleer (2005), who discusses a variety of univariate and multivariate, conditional, stochastic and realized volatility models).

Some recent empirical studies (see, for example, Berkowitz and O'Brien (2001), Gizycki and Hereford (1998), and Pérignon et al. (2008)) have indicated that some financial institutions overestimate their market risks in disclosures to the appropriate regulatory authorities, which can imply a costly restriction to the banks trading activity. ADIs may prefer to report high $\mathrm{VaR}$ numbers to avoid the possibility of regulatory intrusion. This conservative risk reporting suggests that efficiency gains may be feasible. In particular, as ADIs have effective tools for the measurement of market risk, while satisfying the qualitative requirements, ADIs could conceivably reduce daily capital charges by implementing a context-dependent market risk disclosure policy. 
McAleer (2009) and McAleer et al. (2010a) discuss alternative approaches to optimize $\mathrm{VaR}$ and daily capital charges.

The next section describes several volatility models that are widely used to forecast the 1-day ahead conditional variances and VaR thresholds.

\section{Models for Forecasting VaR}

ADIs can use internal models to determine their VaR thresholds. There are alternative time series models for estimating conditional volatility. In what follows, we present several conditional volatility models to evaluate strategic market risk disclosure, namely GARCH, GJR and EGARCH, with Gaussian, Student- $t$ and Generalized Normal distribution errors, where the parameters are estimated.

These models are chosen as they are well known and widely used in the literature. For an extensive discussion of the theoretical properties of several of these models, see Ling and McAleer (2002a, 2002b, 2003a) and Caporin and McAleer (2010b). As an alternative to estimating the parameters, we also consider the exponential weighted moving average (EWMA) method by Riskmetrics (1996) and Zumbauch, (2007) that calibrates the unknown parameters. We include a section on these models to present them in a unified framework and notation, and to make explicit the specific versions we are using. Apart from EWMA, the models are presented in increasing order of complexity.

\subsection{GARCH}

For a wide range of financial data series, time-varying conditional variances can be explained empirically through the autoregressive conditional heteroskedasticity (ARCH) model, which was proposed by Engle (1982). When the time-varying conditional variance has both autoregressive and moving average components, this leads to the generalized $\operatorname{ARCH}(p, q)$, or $\operatorname{GARCH}(p, q)$, model of Bollerslev (1986). It is very common to impose the widely estimated $\operatorname{GARCH}(1,1)$ specification in advance. 
Consider the stationary $\mathrm{AR}(1)-\mathrm{GARCH}(1,1)$ model for daily returns, $y_{t}$ :

$$
y_{t}=\varphi_{1}+\varphi_{2} y_{t-1}+\varepsilon_{t}, \quad\left|\varphi_{2}\right|<1
$$

for $t=1, \ldots, n$, where the shocks to returns are given by:

$$
\begin{aligned}
& \varepsilon_{t}=\eta_{t} \sqrt{h_{t}}, \quad \eta_{t} \sim \operatorname{iid}(0,1) \\
& h_{t}=\omega+\alpha \varepsilon_{t-1}^{2}+\beta h_{t-1},
\end{aligned}
$$

and $\omega>0, \alpha \geq 0, \beta \geq 0$ are sufficient conditions to ensure that the conditional variance $h_{t}>0$. The stationary AR(1)-GARCH $(1,1)$ model can be modified to incorporate a nonstationary $\operatorname{ARMA}(p, q)$ conditional mean and a stationary $\operatorname{GARCH}(r, s)$ conditional variance, as in Ling and McAleer (2003b).

\subsection{GJR}

In the symmetric GARCH model, the effects of positive shocks (or upward movements in daily returns) on the conditional variance, $h_{t}$, are assumed to be the same as the effect of negative shocks (or downward movements in daily returns) of equal magnitude. In order to accommodate asymmetric behaviour, Glosten, Jagannathan and Runkle (1992) proposed a model (hereafter GJR), for which GJR(1,1) is defined as follows:

$$
h_{t}=\omega+\left(\alpha+\gamma I\left(\eta_{t-1}\right)\right) \varepsilon_{t-1}^{2}+\beta h_{t-1},
$$

where $\omega>0, \alpha \geq 0, \alpha+\gamma \geq 0, \beta \geq 0$ are sufficient conditions for $h_{t}>0$, and $I\left(\eta_{t}\right)$ is an indicator variable defined by:

$$
I\left(\eta_{t}\right)= \begin{cases}1, & \varepsilon_{t}<0 \\ 0, & \varepsilon_{t} \geq 0\end{cases}
$$


as $\eta_{t}$ has the same sign as $\varepsilon_{t}$. The indicator variable differentiates between positive and negative shocks, so that asymmetric effects in the data are captured by the coefficient $\gamma$. For financial data, it is expected that $\gamma \geq 0$ because negative shocks have a greater impact on risk than do positive shocks of similar magnitude. The asymmetric effect, $\gamma$, measures the contribution of shocks to both short run persistence, $\alpha+\gamma / 2$, and to long run persistence, $\alpha+\beta+\gamma / 2$. Although GJR permits asymmetric effects of positive and negative shocks of equal magnitude on conditional volatility, the special case of leverage, whereby negative shocks increase volatility while positive shocks decrease volatility (see Black (1976) for an argument using the debt/equity ratio), cannot be accommodated (for further details on asymmetry versus leverage in the GJR model, see Caporin and McAleer (2010b)).

\section{$3.3 \quad$ EGARCH}

An alternative model to capture asymmetric behaviour in the conditional variance is the Exponential GARCH, or EGARCH(1,1), model of Nelson (1991), namely:

$$
\log h_{t}=\omega+\alpha\left|\frac{\varepsilon_{t-1}}{h_{t-1}}\right|+\gamma \frac{\varepsilon_{t-1}}{h_{t-1}}+\beta \log h_{t-1}, \quad|\beta|<1
$$

where the parameters $\alpha, \beta$ and $\gamma$ have different interpretations from those in the $\operatorname{GARCH}(1,1)$ and GJR( 1,1$)$ models.

EGARCH captures asymmetries differently from GJR. The parameters $\alpha$ and $\gamma$ in EGARCH $(1,1)$ represent the magnitude (or size) and sign effects of the standardized residuals, respectively, on the conditional variance, whereas $\alpha$ and $\alpha+\gamma$ represent the effects of positive and negative shocks, respectively, on the conditional variance in GJR(1,1). Unlike GJR, EGARCH can accommodate leverage, depending on the restrictions imposed on the size and sign parameters.

As noted in McAleer et al. (2007), there are some important differences between EGARCH and the previous two models, as follows: (i) EGARCH is a model of the 
logarithm of the conditional variance, which implies that no restrictions on the parameters are required to ensure $h_{t}>0$; (ii) moment conditions are required for the GARCH and GJR models as they are dependent on lagged unconditional shocks, whereas EGARCH does not require moment conditions to be established as it depends on lagged conditional shocks (or standardized residuals); (iii) Shephard (1996) observed that $|\beta|<1$ is likely to be a sufficient condition for consistency of QMLE for EGARCH(1,1); (iv) as the standardized residuals appear in equation (7), $|\beta|<1$ would seem to be a sufficient condition for the existence of moments; and (v) in addition to being a sufficient condition for consistency, $|\beta|<1$ is also likely to be sufficient for asymptotic normality of the QMLE of $\operatorname{EGARCH}(1,1)$.

The three conditional volatility models given above are estimated under the following distributional assumptions on the conditional shocks: (1) Gaussian, (2) Student- $t$, with estimated degrees of freedom, and (3) Generalized Normal. As the models that incorporate the $t$ distributed errors are estimated by QMLE, the resulting estimators are consistent and asymptotically normal, so they can be used for estimation, inference and forecasting.

\subsection{Exponentially Weighted Moving Average (EWMA)}

As an alternative to estimating the parameters of the appropriate conditional volatility models, Riskmetrics (1996) developed a model which estimates the conditional variances and covariances based on the exponentially weighted moving average (EWMA) method, which is, in effect, a restricted version of the $\mathrm{ARCH}(\infty)$ model. This approach forecasts the conditional variance at time $t$ as a linear combination of the lagged conditional variance and the squared unconditional shock at time $t-1$. The EWMA model calibrates the conditional variance as:

$$
h_{t}=\lambda h_{t-1}+(1-\lambda) \varepsilon_{t-1}^{2}
$$


where $\lambda$ is a decay parameter. Riskmetrics (1996) suggests that $\lambda$ should be set at 0.94 for purposes of analysing daily data. As no parameters are estimated, there are no moment or log-moment conditions.

\section{Data}

The data used in estimation and forecasting are the closing daily prices for French CAC 40 (CAC), German DAX 30 (DAX), US Dow Jones 100 (DJ), UK FTSE100 (FTSE), Hong Kong Hang Seng 45 (HSI), Spanish IBEX 35 (IBEX), Japanese Nikkei 225 (Nikkei), Swiss SMI 50 (SMI) and US S\&P500 (S\&P500). They were obtained from the Thomson Reuters-Ecowin Financial Database for the period 3 January 2000 to 14 October 2010.

If $P_{t}$ denotes the market price, the returns at time $t\left(R_{t}\right)$ are defined as:

$$
R_{t}=\log \left(P_{t} / P_{t-1}\right)
$$

\section{[Insert Figures 1-2 and Tables 2-3 here]}

In Figure 1 we show the daily returns of the 9 indices, for which the descriptive statistics are given in Table 2. Extremely high positive and negative returns are evident from September 2008 onward, and have continued well into 2009. The mean is close to zero, and the range is between $-13.6 \%$ (for HSI) and $+13.5 \%$ (for IBEX). Indices display high kurtosis and heavy tails, which is not surprising for daily financial returns data. In Table 2, the Jarque-Bera Lagrange Multiplier test rejects the null hypothesis of normally distributed returns for every index. Figure 3 shows the histograms for each index, together with the theoretical Gaussian and Student-t probability density functions. It seems that the Student-t, density fits the returns distributions better than the Gaussian.

Additionally, it is interesting to examine the returns distributions for the three periods relating to the GFC, namely: before (January-August 2008), during (August 2008March 2009) and after (March 2009- October 2010). As can be seen in Figure 4, there are changes in the shapes of the underlying probability density functions. We graph the empirical distributions, together with the Normal, Student-t and a kernel density 
estimator for the three periods. Clearly, the shape of the densities changes from one period to another for each index.

Apparently, stock returns have similar patterns of variability over time. However, a closer examination of the correlations in Table 3 reveals that: (1) S\&P500 has a very high correlation with DJ (0.97), which are two indices in similar markets; (2) European indices (CAC, DAX, FTSE, IBEX and SMI) have high correlations among themselves, and (3) the correlation between Nikkei and HSI (0.63) is higher than its correlations with European and American indices, and has an especially low correlation with DJ and SP500; in some cases, as low as 0.12 . This suggests that the returns behave somewhat differently in the three geographical areas contained in the sample (namely, USA, Europe and Asia).

As for returns volatility, several measures of volatility are available in the literature. In order to gain some intuition, we adopt the measure proposed in Franses and van Dijk (1999), wherein the true volatility of returns is defined as:

$$
V_{t}=\left(R_{t}-E\left(R_{t} \mid F_{t-1}\right)\right)^{2}
$$

where $F_{t-1}$ is the information set at time $t-1$. Figure 2 presents the square root of $V_{t}$ in equation (11) as "volatilities". The series exhibit clusterings that needs to be captured by an appropriate time series model. The volatility of the series appears to be high during the early 2000s, followed by a quiet period from 2003 to the beginning of 2007 . Volatility increases dramatically after August 2008, due in large part to the worsening global credit environment. This increase in volatility is even higher in October 2008. For example, in less than four weeks in October 2008, the S\&P500 index plummeted by 27.1\%. In less than three weeks in November 2008, starting the morning after the US elections, the SP500 index plunged a further 25.2\%. Overall, from late August 2008, US stocks fell by a scarcely believable $42.2 \%$ to reach a low on 20 November 2008. Similar highly volatile behaviour is observed in several of the remaining indices.

Table 4 displays the correlation between the volatilities of returns for the period January 2008 to November 2010. The correlation between DJ and S\&P500 is high (at 0.98), 
which is hardly surprising since they both refer to the US market. The linear relationship in the volatility between the remainder of the indexes is not uniform, with a maximum of 0.90 between CAC and FTSE and a minimum of 0.29 between HSI and Nikkei. Correlations between the volatilities of returns in European markets are higher than the correlations between these indices and those in other markets. From the above we can conclude that there is a noticeable heterogeneity among the indices, so it is possible to benefit from such diversity.

\section{Robust Forecasting of VaR and Evaluation Framework}

As discussed in McAleer et al. (2010c), the GFC has affected the best risk management strategies by changing the optimal model for minimizing daily capital charges. The objective in this section is to provide a robust risk management strategy, namely one that does not change over time, even in the presence of a GFC. This robust risk management strategy also has to lead to daily capital charges that are not excessive, and to violation frequencies that are compatible with the Basel II Accord penalty structure.

ADIs need not restrict themselves to using only a single risk model. We propose a risk management strategy that consists in choosing a forecast from among different combinations of alternative univariate risk models for VaR. McAleer et al. (2010c) developed a risk management strategy that used combinations of several models for forecasting $\mathrm{VaR}$. It was found that an aggressive risk management strategy (namely, choosing the Supremum of VaR forecasts, or an upperbound) yielded the lowest mean capital charges and largest number of violations. On the other hand, a conservative risk management strategy (namely, by choosing the Infinum, or lowerbound) had far fewer violations, and correspondingly higher mean daily capital charges.

In this paper, we forecast VaR using combinations of the forecasts of individual VaR models, namely the $r$ th percentile of the $\mathrm{VaR}$ forecasts of a set of univariate conditional volatility models. Alternative single models with different error distributions and several different combinations of models are compared over three different time periods to investigate which, if any, of the risk management strategies may be robust. 
We conduct an exercise to analyze the performance of existing VaR forecasting models, as permitted under the Basel II framework, when applied to the French CAC, German DAX, US Dow Jones, UK FTSE, Hong Kong Hang Seng, Spanish IBEX, Japanese Nikkei, Swiss SMI and US S\&P500.

For each index we use four different models, ARCH, EGARCH, GJR and Riskmetrics, and for each of the first three conditional volatility models, we use three distribution errors, namely Gaussian, Student-t and Generalized Normal.

In addition, we analyze twelve new strategies based on combinations of the previous standard single-model forecasts of VaR, namely: the Average, Infinum ( $0^{\text {th }}$ percentile), Supremum $\left(100^{\text {th }}\right.$ percentile $)$, and nine additional strategies based on the $10^{\text {th }}$ through to the $90^{\text {th }}$ percentiles, which includes the Median $\left(50^{\text {th }}\right.$ percentile $){ }^{7}$

We will examine whether it is possible to select a robust VaR forecast irrespective of the time period, while providing reasonable daily capital charges and numbers of violations.

\subsection{Evaluating Crisis-Robust Risk Management Strategies}

In Tables 5 and 6, the performance of the different VaR forecasting models is evaluated using several standard criteria that are relevant for the risk manager, namely: daily capital charges (DCC), number of violations (NoV), accumulated losses ${ }^{8}$ (AcLoss), and the value of the asymmetric linear tick loss function ${ }^{9}$ (AlTick) that allows a comparison of model performance.

\footnotetext{
${ }^{7}$ Analysis has been done for nine percentiles (available upon request). In the paper, only the results for the Median strategy are shown.

${ }^{8}$ López (1999) suggested measuring the accuracy of the VaR forecast on the basis of the distance between the observed returns and the forecasted $\mathrm{VaR}$ values if a violation occurs:

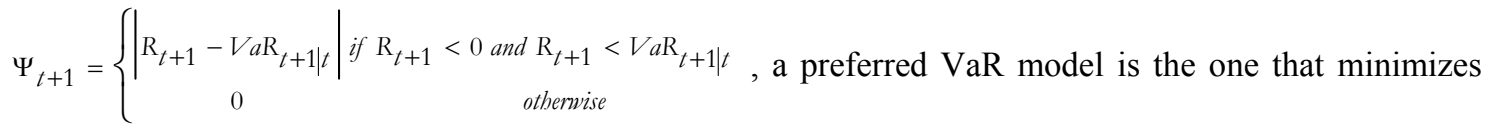
the total loss value, $\Psi_{t+1}=\sum_{t=1}^{T} \Psi_{t}$.

${ }^{9}$ The tick loss function of order $\alpha$ defined as $L_{\alpha}\left(e_{t+1}\right)=\left(\alpha-1\left(e_{t+1}<0\right)\right) e_{t+1}$, where $e_{t+1}=R_{t+1}-V a R_{t+1}$.
} 
The performance criteria are calculated for each model and error distribution, and for each of the three sub-samples, before, during, and after the 2008-09 GFC, where, for most indices $^{10}$, before is from 2 January 2008 to 11 August 2008, during is from 11 August 2008 to 9 March 2009, and after is from 9 March 2009 to 14 October 2010.

No risk model is found to be superior to its competitors in all situations as there is no strategy that optimizes every evaluation statistic for the three sub-periods. Nonetheless, the Median is found to be robust as it produces adequate VaR forecasts that exhibit stable and, very often, superior results across different periods relative to other risk models.

\section{[Insert Tables 5-6 here]}

In Table 5, we have the ranking of the strategies for each index according to the daily capital charges (DCC). Table 5a contains the information relative to the before the GFC, Table $5 \mathrm{~b}$ corresponds to the GFC, and Table $5 \mathrm{c}$ is after the GFC. Additionally, each cell shows the number of violations $(\mathrm{NoV})$ as the middle number, together with the accumulated losses for each model (bottom). We comment on the rankings for the cases in which the number of violations is less than or equal to 8 , which is the upper threshold beyond which it might be perceived as being too close to the red zone.

\section{(i) Daily capital charges and number of violations:}

1. Before the GFC, the best strategy for minimizing DCC and staying below 8 violations is the Supremum, for 6 of 9 indices. The second best strategy is EGARCH for 3 of 9 indices. Riskmetrics is also superior to the Median for 8 of 9 indices. However, the best strategy for staying in the green zone (up to 4 violations) is the Median (for 8 of 9 indices).

2. During the GFC, the Supremum violates more than 8 times in 7 of 9 indices, while Riskmetrics violates more than 8 times for 5 of 9 indices. However, the

\footnotetext{
${ }^{10}$ The precise dates for the beginning and ending of the GFC for each index, based on the peaks and troughs of the respective indexes, are as follows: CAC from 2/9/2008 to 9/3/2009; DAX from 11/8/2008 to 6/3/2009; DJ from 11/9/2008 to $9 / 3 / 2009$; FTSE from 29/8/2008 to 3/3/2009; HSHK from 1/1/2008 to 9/3/2009; IBEX from 11/8/2008 to 9/3/2009; Nikkei from 11/8/2008 to 10/3/2009; SMI from 11/8/2008 to $9 / 3 / 2009$; S\&P500 from 11/8/2008 to $9 / 3 / 2009$.
} 
Median is superior to Riskmetrics for 5 indices, while it maintains fewer than 8 violations for 8 of 9 indices.

3. After the GFC, the Supremum is best for 5 of 9 indices, but violates heavily for the remaining 4 indices. In second place, for 2 of 9 cases, is EGARCH, but it also tends to violate more frequently. The Median is a strategy in the green zone or with fewer than 8 violations for all indices, while it is superior to Riskmetrics in terms of DCC for 5 of 9 indices.

In summary, the Median is a risk management strategy that is in the green zone before the GFC, and has fewer than 8 violations during and after the GFC. While some competing strategies perform better before the crisis, they tend to violate too often during and after the crisis.

(ii) Accumulated losses. An additional criterion that is complementary to the daily capital charges is the accumulated losses, namely the sum of the total losses implied by each strategy for a given index.

1. Before the GFC, the Median implies accumulated losses that are lower than its leading competitors, namely, Supremum, EGARCH and Riskmetrics for 23 of 27 cases. The 27 cases arise from 9 indices for three total outcomes, namely whether it is or is not superior to the Median strategy when compared with the other three strategies.

2. During the GFC, the Median implies accumulated losses that are lower than its leading competitors, that is, Supremum, EGARCH and Riskmetrics for 26 of 27 cases.

3. After the GFC, the Median implies accumulated losses that are lower than its leading competitors, that is, Supremum, EGARCH and Riskmetrics for 23 of 27 cases.

The accumulated losses (AcLoss) are an important complementary criterion to those of daily capital charges (DCC) and the number of violations (NoV). The accumulated losses are related to the size (and number) of violations, and both are considered by regulators in order to decide whether an internal risk forecasting model is acceptable for a given ADI. 


\section{(iii) Asymmetric linear tick loss function:}

Another complementary criterion is the asymmetric linear tick loss function. This criterion is the objective function used to estimate quantiles. As we are proposing to use strategies based on quantiles of the individual forecasts, this is a relevant criterion. In Tables 6a-6c, we present the rankings of the strategies for each index according to the asymmetric linear tick loss function. Table 6a contains the information relative to before the GFC, Table $6 \mathrm{~b}$ corresponds to the GFC, and Table $6 \mathrm{c}$ refers to after the GFC.

In what follows, we analyse the performance of the Median relative to its leading competitors:

1. Before the GFC, the Median has values of the asymmetric linear tick loss function that are always superior, for all indices, to its leading competitors, namely, Supremum and Riskmetrics. In addition, EGARCH has lower (better) values than the Median for 6 of 9 indices, and would be preferred before the GFC according to this criterion.

2. During the GFC, the Median implies values of the asymmetric linear tick loss function that are better than those of Supremum, EGARCH and Riskmetrics for 26 of 27 cases. This suggests that the Median would again be a sensible strategy for managing risk during the GFC.

3. After the GFC, the Median implies values of the asymmetric linear tick loss function that are better (lower) than its leading competitors, namely, Supremum, EGARCH and Riskmetrics for 23 of 27 cases, which reinforces the previous conclusions that are favourable to the Median.

\section{Conclusion}

In this paper we proposed a strategy for obtaining robust risk forecasts that use combinations of several conditional volatility models to forecast VaR. Different strategies for combining models were compared over three different time periods, using a variety of international indices that included French CAC, German DAX, US Dow 
Jones, UK FTSE100, Hong Kong Hang Seng, Spanish Ibex35, Japanese Nikkei, Swiss SMI and US S\&P500.

A set of 14 models and combinations of models were used for each index. We started with 4 different univariate models, namely ARCH, EGARCH, GJR and Riskmetrics, and for each of the first 3 conditional volatility models we considered three distributions for the errors, namely Gaussian, Student-t and Generalized Normal. Additionally, we presented 4 new strategies based on combinations of standard univariate VaR model forecasts, namely Infinum and Supremum (as developed in McAleer et al. (2010a)), Average and Median.

We investigated whether it was possible to determine a GFC-robust risk management strategy. Backtesting provided evidence that a risk management strategy based on VaR forecasts corresponding to the $50^{\text {th }}$ percentile (or Median) of the VaR forecasts of a set of univariate conditional volatility models was robust, in that it yielded reasonable daily capital charges, numbers of violations that did not jeopardize institutions that might consider using such a strategy and, more importantly, was invariant before, during and after the 2008-09 GFC.

The principal findings can be summarized as follows:

1. Before the GFC, the best strategy for minimizing DCC and remaining below 8 violations is the Supremum for 6 of 9 indices. The second best strategy is EGARCH for 3 of 9 indices. Riskmetrics is also superior to the Median for 8 of 9 indices. However, the best strategy for remaining in the green zone (namely, up to 4 violations), which is typically desired by ADIs, is the Median (for 8 of 9 indices).

2. During the GFC, the Supremum violates more than 8 times for 7 of 9 indices, while Riskmetrics violates more than 8 times for 5 of 9 indices. However, the Median is superior to Riskmetrics for 5 indices, while it maintains fewer than 8 violations for 8 of 9 indices.

3. After the GFC, the Supremum is the best strategy for 5 of 9 indices, but violates heavily for the remaining indices. In second place, for 2 of 9 cases, is EGARCH, but it also tends to violate heavily for the other indices. The Median strategy 
remains in the green zone, or has fewer than 8 violations, for all indices, while it is superior to Riskmetrics for 5 of 9 indices.

In summary, the Median is a risk management strategy that remains in the green zone before the GFC, and with fewer than 8 violations during and after the GFC. While some competing strategies perform better before the GFC, they tend to violate too often during and after the GFC. The analysis of complementary criteria, such as the accumulated losses and asymmetric linear tick loss function, reinforce the previous conclusions regarding overall forecasting performance.

The attraction for risk managers in using the Median strategy is that they do not need to keep changing the rules for generating daily VaR forecasts. The Median is a prudent and profitable rule for calculating VaR forecasts, both in tranquil and turbulent times.

The idea of combining different $\mathrm{VaR}$ forecasting models is entirely within the spirit of the Basel Accord, although its use would require approval by the regulatory authorities, as for any forecasting model. This approach is not computationally demanding, even though several models need to be specified and estimated over time. Further research is needed to compute the standard errors of the forecasts of the combined models, including the Median forecast strategy. 


\section{References}

Basel Committee on Banking Supervision, (1988), International Convergence of Capital Measurement and Capital Standards, BIS, Basel, Switzerland.

Basel Committee on Banking Supervision, (1995), An Internal Model-Based Approach to Market Risk Capital Requirements, BIS, Basel, Switzerland.

Basel Committee on Banking Supervision, (1996), Supervisory Framework for the Use of "Backtesting" in Conjunction with the Internal Model-Based Approach to Market Risk Capital Requirements, BIS, Basel, Switzerland.

Basel Committee on Banking Supervision, (2006), International Convergence of Capital Measurement and Capital Standards, a Revised Framework Comprehensive Version, BIS, Basel, Switzerland.

Berkowitz, J. and J. O'Brien (2001), How accurate are value-at-risk models at commercial banks?, Discussion Paper, Federal Reserve Board.

Black, F. (1976), Studies of stock market volatility changes, in 1976 Proceedings of the American Statistical Association, Business \& Economic Statistics Section, pp. 177-181.

Bollerslev, T. (1986), Generalised autoregressive conditional heteroscedasticity, Journal of Econometrics, 31, 307-327.

Borio, C. (2008), The financial turmoil of 2007-?: A preliminary assessment and some policy considerations, BIS Working Papers No 251, Bank for International Settlements, Basel, Switzerland.

Caporin, M. and M. McAleer (2010a), The Ten Commandments for managing investments, Journal of Economic Surveys, 24, 196-200.

Caporin, M. and M. McAleer (2010b), Model selection and testing of conditional and stochastic volatility models, to appear in L. Bauwens, C. Hafner and S. Laurent (eds.), Handbook on Financial Engineering and Econometrics: Volatility Models and Their Applications, Wiley, New York (Available at SSRN: http://ssrn.com/abstract=1676826).

Engle, R.F. (1982), Autoregressive conditional heteroscedasticity with estimates of the variance of United Kingdom inflation, Econometrica, 50, 987-1007.

Franses, P.H. and D. van Dijk (1999), Nonlinear Time Series Models in Empirical Finance, Cambridge, Cambridge University Press. 
Gizycki, M. and N. Hereford (1998), Assessing the dispersion in banks' estimates of market risk: the results of a value-at-risk survey, Discussion Paper 1, Australian Prudential Regulation Authority.

Glosten, L., R. Jagannathan and D. Runkle (1992), On the relation between the expected value and volatility of nominal excess return on stocks, Journal of Finance, 46, 17791801.

Jimenez-Martin, J.-A., McAleer, M. and T. Pérez-Amaral (2009), The Ten Commandments for managing value-at-risk under the Basel II Accord, Journal of Economic Surveys, 23, 850-855.

Jorion, P. (2000), Value at Risk: The New Benchmark for Managing Financial Risk, McGraw-Hill, New York.

Li, W.K., S. Ling and M. McAleer (2002), Recent theoretical results for time series models with GARCH errors, Journal of Economic Surveys, 16, 245-269. Reprinted in M. McAleer and L. Oxley (eds.), Contributions to Financial Econometrics: Theoretical and Practical Issues, Blackwell, Oxford, 2002, pp. 9-33.

Ling, S. and M. McAleer (2002a), Stationarity and the existence of moments of a family of GARCH processes, Journal of Econometrics, 106, 109-117.

Ling, S. and M. McAleer (2002b), Necessary and sufficient moment conditions for the $\operatorname{GARCH}(\mathrm{r}, \mathrm{s})$ and asymmetric power GARCH$(\mathrm{r}, \mathrm{s})$ models, Econometric Theory, 18, 722-729.

Ling, S. and M. McAleer, (2003a), Asymptotic theory for a vector ARMA-GARCH model, Econometric Theory, 19, 278-308.

Ling, S. and M. McAleer (2003b), On adaptive estimation in nonstationary ARMA models with GARCH errors, Annals of Statistics, 31, 642-674.

Lopez, J.A. (1999), Methods for evaluating value-at-risk estimates, Economic Review, Federal Reserve Bank of San Francisco, pp. 3-17.

McAleer, M. (2005), Automated inference and learning in modeling financial volatility, Econometric Theory, 21, 232-261.

McAleer, M. (2009), The Ten Commandments for optimizing value-at-risk and daily capital charges, Journal of Economic Surveys, 23, 831-849.

McAleer, M., F. Chan and D. Marinova (2007), An econometric analysis of asymmetric volatility: theory and application to patents, Journal of Econometrics, 139, 259-284. 
McAleer, M., J.-Á. Jiménez-Martin and T. Pérez-Amaral (2010a), A decision rule to minimize daily capital charges in forecasting value-at-risk, Journal of Forecasting, 29, 617-634.

McAleer, Michael, J-A., Jiménez-Martin and T. Perez Amaral (2010b), Has the Basel II Accord encouraged risk management during the 2008-09 financial crisis?, Available at SSRN: http://ssrn.com/abstract=1397239.

McAleer, Michael, J-A. Jiménez-Martin, Juan-Angel and T. Perez Amaral, (2010c), GFCrobust risk management strategies under the Basel Accord, Available at SSRN: http://ssrn.com/abstract=1688385.

McAleer, M. and B. da Veiga (2008a), Forecasting value-at-risk with a parsimonious portfolio spillover GARCH (PS-GARCH) model, Journal of Forecasting, 27, 1-19.

McAleer, M. and B. da Veiga (2008b), Single index and portfolio models for forecasting value-at-risk thresholds, Journal of Forecasting, 27, 217-235.

Nelson, D.B. (1991), Conditional heteroscedasticity in asset returns: a new approach, Econometrica, 59, 347-370.

Pérignon, C., Z.Y. Deng and Z.J. Wang (2008), Do banks overstate their value-at-risk?, Journal of Banking \& Finance, 32, 783-794.

Riskmetrics (1996), J.P. Morgan Technical Document, $4^{\text {th }}$ Edition, New York, J.P. Morgan.

Shephard, N. (1996), Statistical aspects of ARCH and stochastic volatility, in O.E. BarndorffNielsen, D.R. Cox and D.V. Hinkley (eds.), Statistical Models in Econometrics, Finance and Other Fields, Chapman \& Hall, London, 1-67.

Stahl, G. (1997), Three cheers, Risk, 10, pp. 67-69.

Zumbauch, G. (2007), A Gentle Introduction to the RM 2006 Methodology, New York, Riskmetrics Group. 
Figure 1. Daily Returns

3 January 2000 - 14 October 2010

CAC

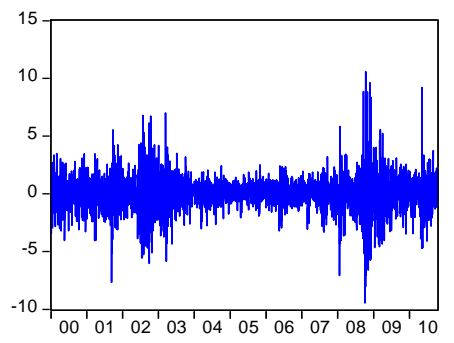

FTSE

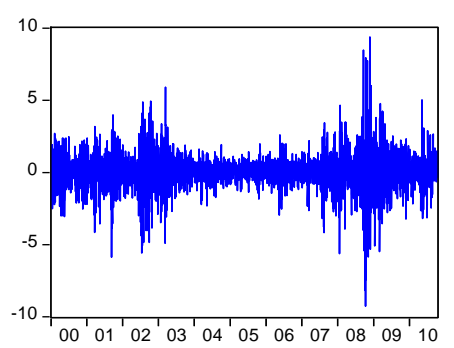

NIKKEI

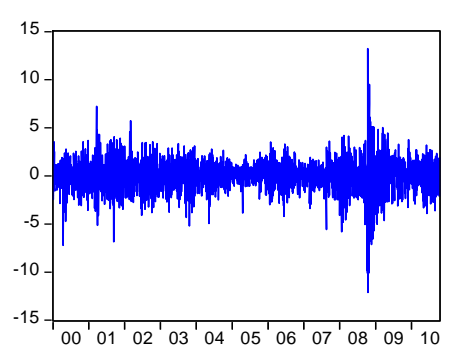

DAX

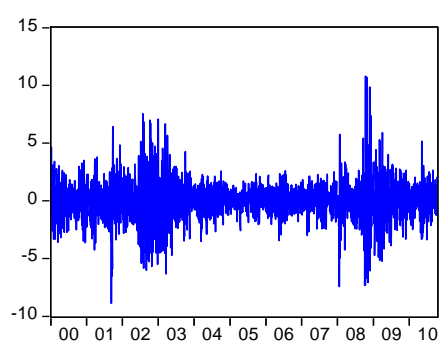

$\mathrm{HSI}$

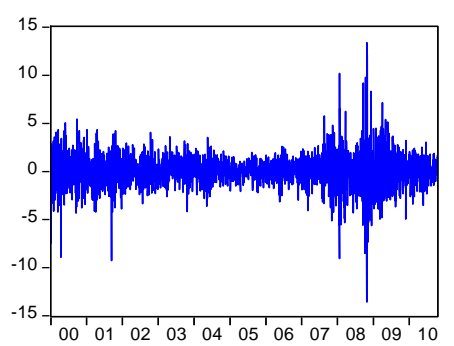

SMI

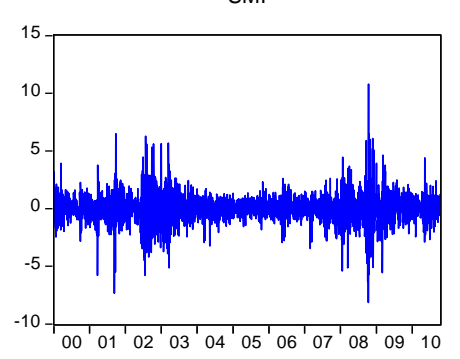

DJI

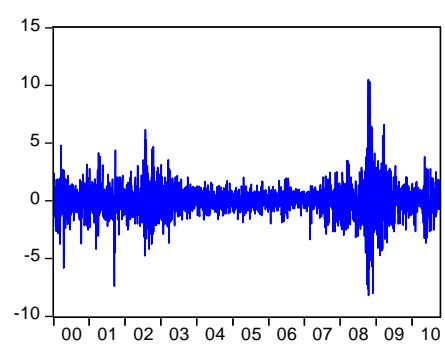

IBEX

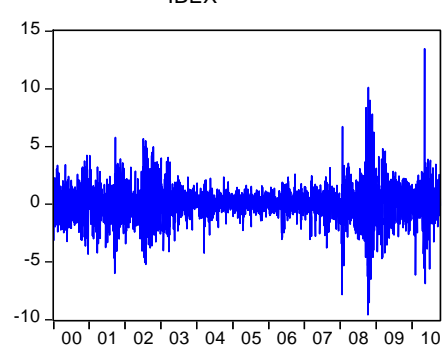

S\&P500

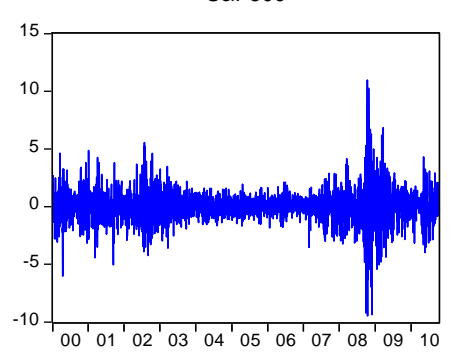


Figure 2. Volatility of Daily Returns

3 January 2000 - 14 October 2010

CAC

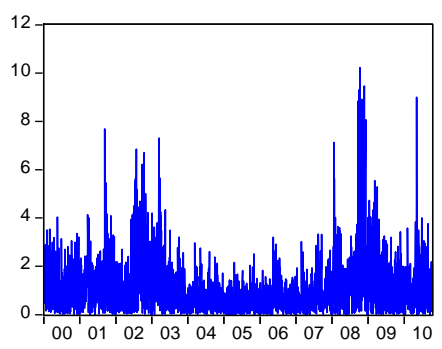

FTSE

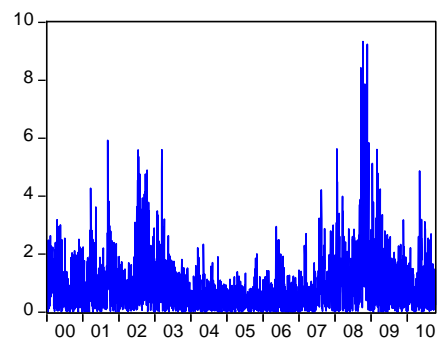

NIKKEI

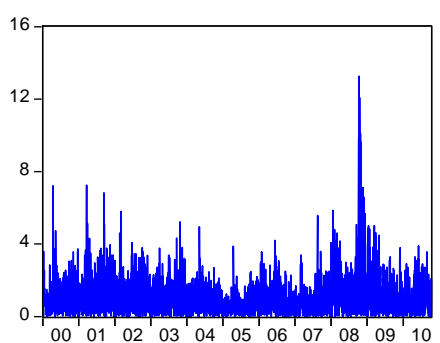

DAX

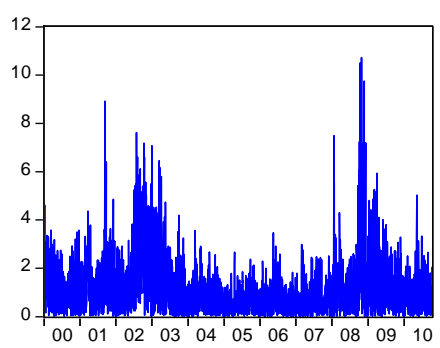

HSHK

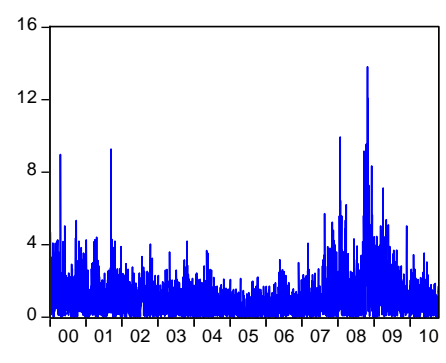

SMl

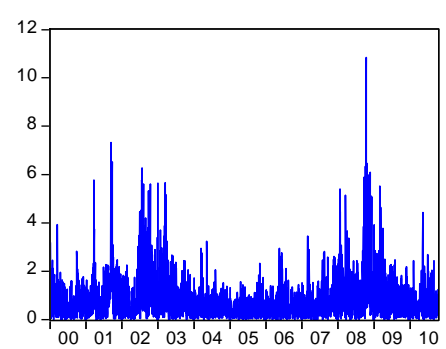

$\mathrm{DJI}$

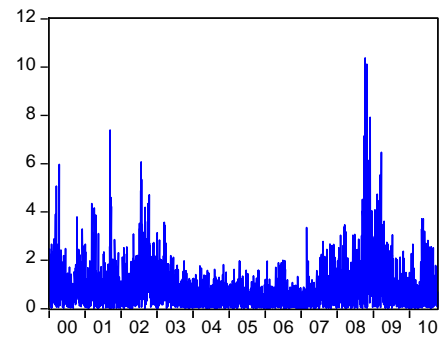

IBEX

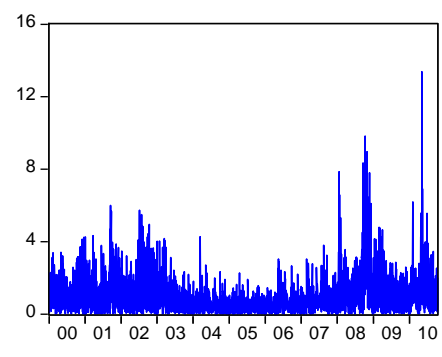

SP500

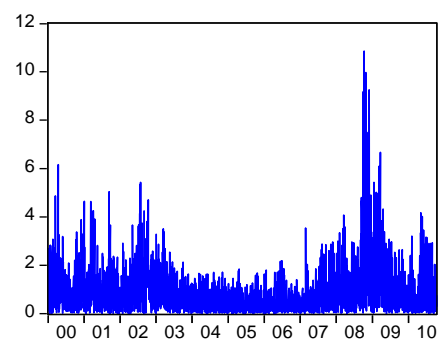


Figure 3. Histograms and theoretical Normal and Student-t distributions

3 January 2000 - 14 October 2010
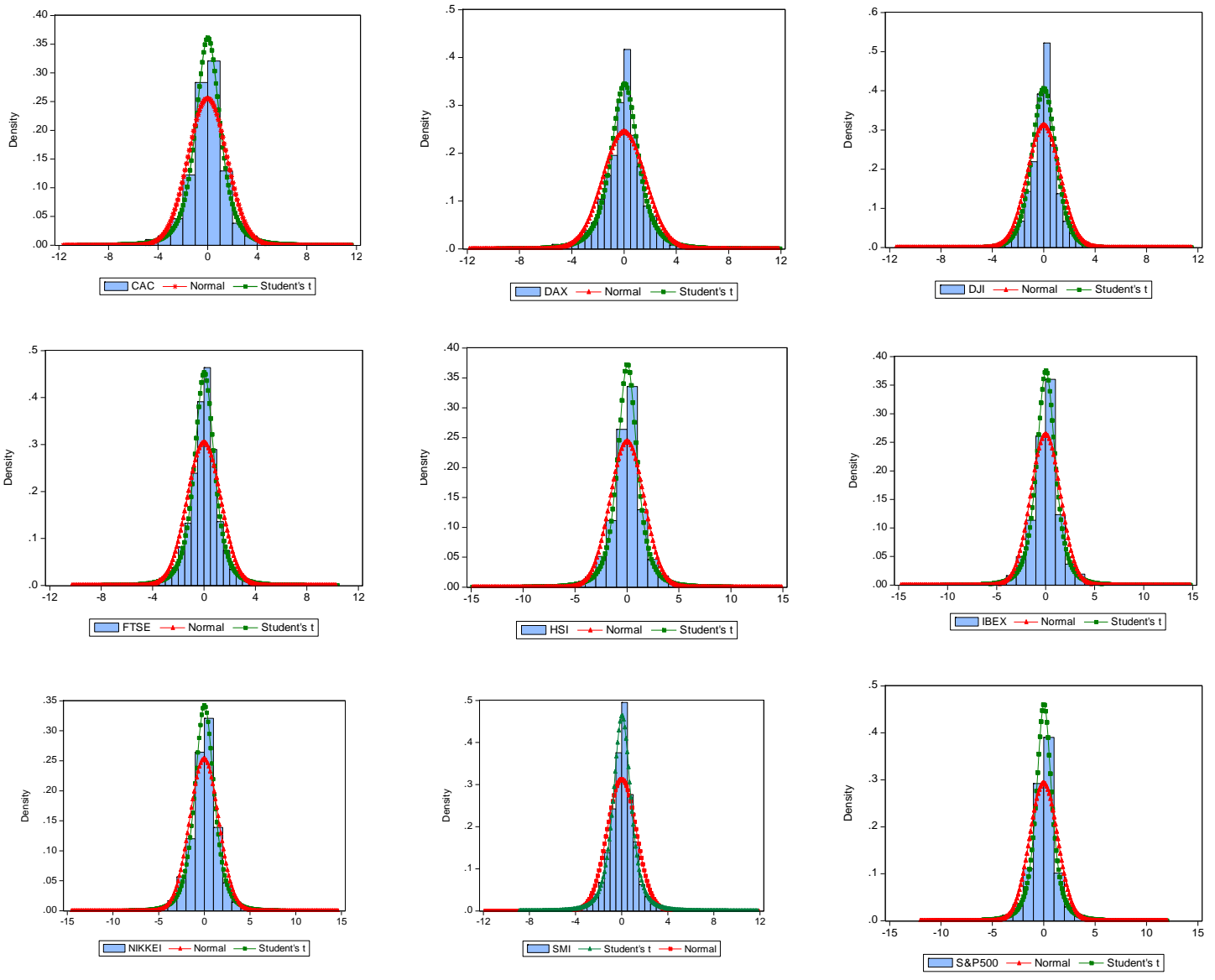
Figure 4. Histograms, Normal, Student-t and Pareto distributions

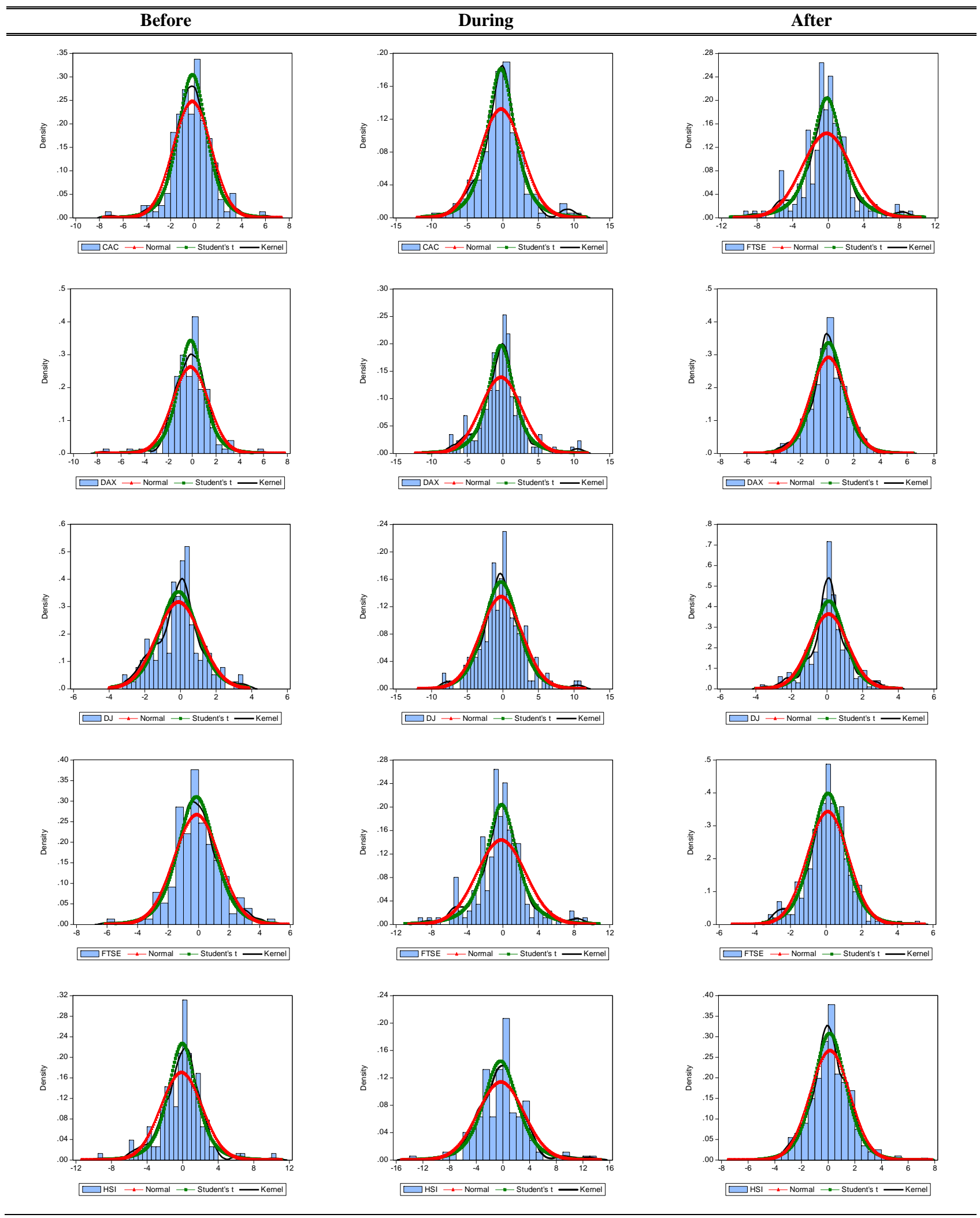


Figure 4 (continued). Histograms, Normal, Student-t and Pareto distributions
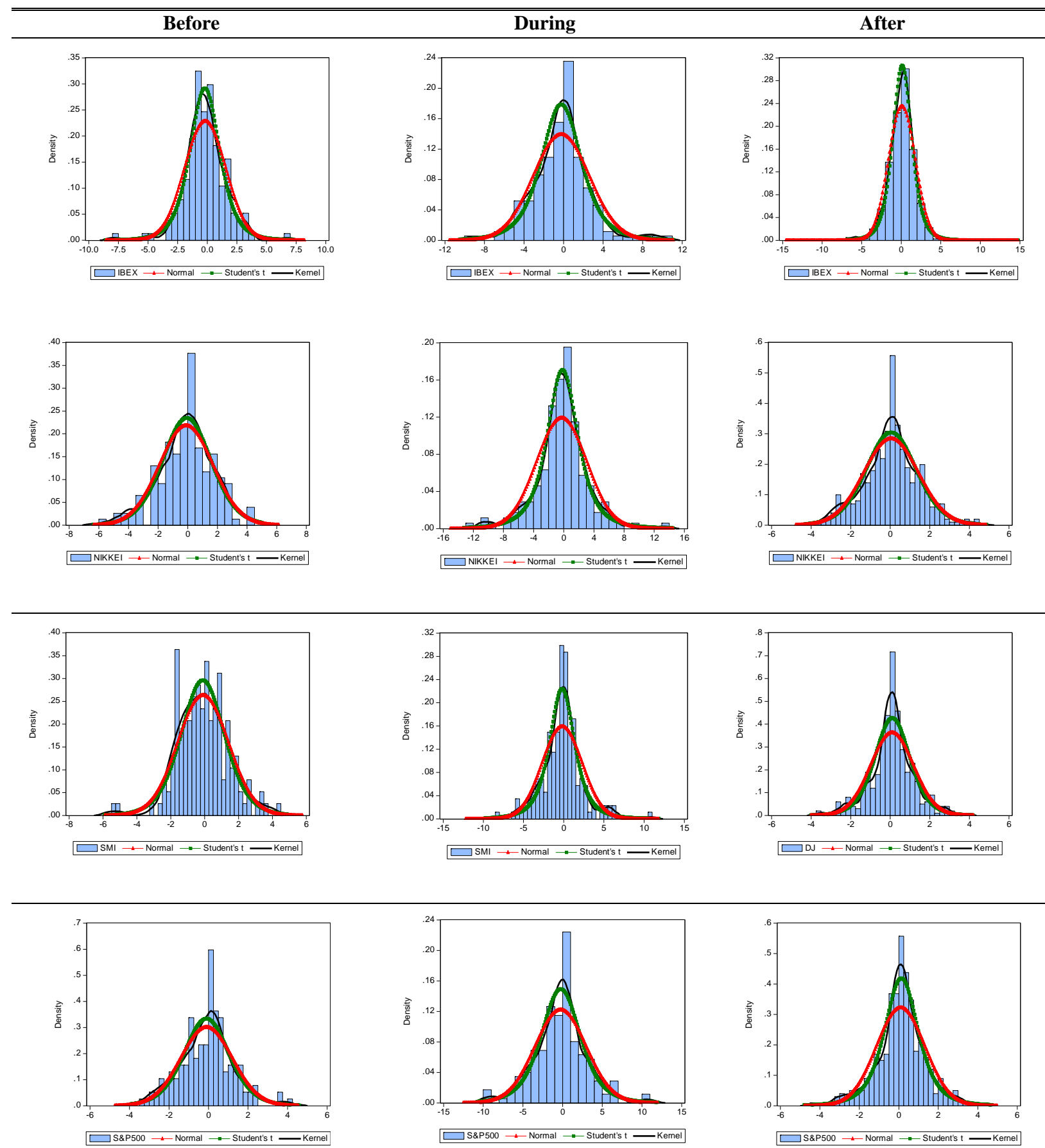
Table 1. Basel Accord Penalty Zones

\begin{tabular}{|l|c|c|}
\hline Zone & Number of Violations & $k$ \\
\hline Green & 0 to 4 & 0.00 \\
\hline Yellow & 5 & 0.40 \\
& 6 & 0.50 \\
& 7 & 0.65 \\
& 8 & 0.75 \\
& 9 & 0.85 \\
\hline Red & $10+$ & 1.00 \\
\hline $\begin{array}{l}\text { Note: The number of violations is given for 250 business days. The } \\
\text { penalty structure under the Basel II Accord is specified for the number } \\
\text { of violations and not their magnitude, either individually or } \\
\text { cumulatively. }\end{array}$ \\
\hline
\end{tabular}


Table 2. Descriptive Statistics

3 January 2000 - 14 October 2010

\begin{tabular}{c|ccccccccc}
\hline \hline \multicolumn{1}{c}{ CAC } & DAX & DJI & FTSE & HSI & IBEX & NIKKEI & SMI & S\&P500 \\
\hline Mean & -0.014 & -0.001 & 0.000 & -0.005 & 0.012 & -0.001 & -0.024 & 0.004 & -0.006 \\
Median & 0.000 & 0.034 & 0.011 & 0.000 & 0.000 & 0.037 & 0.000 & 0.013 & 0.008 \\
Max. & 10.60 & 10.80 & 10.50 & 9.40 & 13.40 & 13.50 & 13.20 & 10.80 & 10.90 \\
Min. & -9.50 & -8.90 & -8.20 & -9.30 & -13.60 & -9.60 & -12.10 & -8.10 & -9.50 \\
Std. Dev. & 1.56 & 1.63 & 1.28 & 1.31 & 1.63 & 1.51 & 1.57 & 1.28 & 1.36 \\
Skew. & 0.06 & 0.04 & 0.01 & -0.13 & -0.05 & 0.14 & -0.31 & 0.02 & -0.11 \\
Kurt. & 8.17 & 7.48 & 10.82 & 9.29 & 11.22 & 9.35 & 9.60 & 9.46 & 10.84 \\
J-B & 3134.3 & 2352.1 & 7163.6 & 4637.4 & 7919.3 & 4737.4 & 5135.9 & 4882.0 & 7202.2 \\
Prob. & 0.000 & 0.000 & 0.000 & 0.000 & 0.000 & 0.000 & 0.000 & 0.000 & 0.000 \\
\hline \hline
\end{tabular}


Table 3. Correlations between Index Returns

3 January 2000 - 14 October 2010

\begin{tabular}{|c|c|c|c|c|c|c|c|c|c|}
\hline Index & CAC & DAX & DJI & FTSE & HSI & IBEX & NIKKEI & SMI & S\&P500 \\
\hline CAC & 1 & & & & & & & & \\
\hline DAX & 0.87 & 1 & & & & & & & \\
\hline DJI & 0.52 & 0.57 & 1 & & & & & & \\
\hline FTSE & 0.89 & 0.80 & 0.50 & 1 & & & & & \\
\hline HSI & 0.36 & 0.32 & 0.20 & 0.36 & 1 & & & & \\
\hline IBEX & 0.88 & 0.79 & 0.49 & 0.81 & 0.35 & 1 & & & \\
\hline NIKKEI & 0.30 & 0.26 & 0.12 & 0.30 & 0.58 & 0.28 & 1 & & \\
\hline SMI & 0.83 & 0.78 & 0.48 & 0.81 & 0.32 & 0.77 & 0.30 & 1 & \\
\hline S\&P500 & 0.54 & 0.58 & 0.97 & 0.51 & 0.21 & 0.50 & 0.12 & 0.48 & 1 \\
\hline
\end{tabular}


Table 4. Correlations between Index Standard Deviations

3 January 2008 - 14 October 2010

\begin{tabular}{|c|c|c|c|c|c|c|c|c|c|}
\hline Index & CAC & DAX & DJI & FTSE & HSI & IBEX & NIKKEI & SMI & S\&P500 \\
\hline CAC & 1 & & & & & & & & \\
\hline DAX & 0.86 & 1.00 & & & & & & & \\
\hline DJI & 0.57 & 0.62 & 1.00 & & & & & & \\
\hline FTSE & 0.90 & 0.80 & 0.54 & 1.00 & & & & & \\
\hline HSI & 0.40 & 0.44 & 0.37 & 0.41 & 1.00 & & & & \\
\hline IBEX & 0.85 & 0.76 & 0.50 & 0.78 & 0.36 & 1.00 & & & \\
\hline NIKKEI & 0.41 & 0.43 & 0.54 & 0.40 & 0.29 & 0.40 & 1.00 & & \\
\hline SMI & 0.81 & 0.73 & 0.53 & 0.81 & 0.41 & 0.74 & 0.43 & 1.00 & \\
\hline S\&P500 & 0.57 & 0.62 & 0.98 & 0.54 & 0.36 & 0.50 & 0.54 & 0.53 & 1.00 \\
\hline
\end{tabular}


Table 5a. Daily Capital Charges Rankings - Before GFC

\begin{tabular}{|c|c|c|c|c|c|c|c|c|c|}
\hline & CAC & DAX & DJ100 & FTSE & HSHK & IBEX & NIKKEI & SMI & SP500 \\
\hline & $\begin{array}{c}\text { SUP } \\
-7.2- \\
(\mathbf{5 . 5 5} \%)\end{array}$ & $\begin{array}{c}\text { SUP } \\
-6.4- \\
(\mathbf{6 . 9} \%)\end{array}$ & $\begin{array}{c}\text { SUP } \\
-6.4- \\
(\mathbf{2 . 0} \%)\end{array}$ & $\begin{array}{c}\text { SUP } \\
-7.3- \\
(\mathbf{6 . 6} \%)\end{array}$ & $\begin{array}{c}\text { EGARCH } \\
-6.6- \\
(\mathbf{5 . 6} \%)\end{array}$ & $\begin{array}{c}\text { EGARCH } \\
-4.8- \\
(\mathbf{6 . 6} \%)\end{array}$ & $\begin{array}{c}\text { SUP } \\
-8.0- \\
(4.6 \%)\end{array}$ & $\begin{array}{c}\text { SUP } \\
-8.0- \\
(5.1 \%)\end{array}$ & $\begin{array}{c}\text { SUP } \\
-9.6- \\
(2.1 \%)\end{array}$ \\
\hline & $\begin{array}{c}\text { GARCH } \\
-5.8- \\
(\mathbf{5 . 2 2} \%)\end{array}$ & $\begin{array}{c}\text { EGARCH } \\
\text { - 3.2- } \\
\mathbf{( 4 . 2 \% )}\end{array}$ & $\begin{array}{c}\text { GARCH } \\
-6.4- \\
(2.0 \%)\end{array}$ & $\begin{array}{c}\text { EGARCH } \\
-5.8 \text { - } \\
(\mathbf{4 . 0} \%)\end{array}$ & $\begin{array}{c}\text { SUP } \\
-1.7- \\
(0.5 \%)\end{array}$ & $\begin{array}{c}\text { SUP } \\
-8.0- \\
(8.2 \%)\end{array}$ & $\begin{array}{c}\text { EGARCH } \\
-8.0 \\
(\mathbf{4 . 5 \% )}\end{array}$ & $\begin{array}{c}\text { EGARCH } \\
-3.2- \\
(\mathbf{2 . 7} \%)\end{array}$ & $\begin{array}{c}\text { EGARCH } \\
\mathbf{- 6 . 4 -} \\
(\mathbf{1 . 1} \%)\end{array}$ \\
\hline & $\begin{array}{c}\text { EGARCH } \\
-4.3- \\
(4.0 \%) \\
\end{array}$ & $\begin{array}{c}\text { GARCH } \\
-4.8- \\
(\mathbf{6 . 2} \%)\end{array}$ & $\begin{array}{c}\text { RSKM } \\
-4.8- \\
(\mathbf{1 . 7} \%)\end{array}$ & $\begin{array}{c}\text { GJR } \\
-5.8- \\
(\mathbf{4 . 7} \%)\end{array}$ & $\begin{array}{c}\text { GJR } \\
-6.6- \\
(5.5 \%)\end{array}$ & $\begin{array}{c}\text { GARCH } \\
-6.4- \\
(\mathbf{6 . 9} \%)\end{array}$ & $\begin{array}{c}\text { GARCH } \\
-4.8- \\
(2.0 \%)\end{array}$ & $\begin{array}{c}\text { GJR } \\
-4.8- \\
(3.4 \%)\end{array}$ & $\begin{array}{c}\text { GARCH } \\
-\mathbf{9 . 6}- \\
(\mathbf{1 . 9} \%)\end{array}$ \\
\hline & $\begin{array}{c}\text { RSKM } \\
-2.9- \\
(5.1 \%)\end{array}$ & $\begin{array}{c}\text { RSKM } \\
-6.4- \\
(6.5 \%)\end{array}$ & $\begin{array}{c}\text { EGARCH } \\
\text { - 6.4- } \\
(\mathbf{1 . 0} \%)\end{array}$ & $\begin{array}{c}\text { EGARCH_G } \\
-4.4- \\
(3.7 \%)\end{array}$ & $\begin{array}{c}\text { GARCH } \\
\text { - } 6.6- \\
(\mathbf{5 . 4} \%)\end{array}$ & $\begin{array}{c}\text { RSKM } \\
-3.2- \\
(7.0 \%)\end{array}$ & $\begin{array}{c}\text { RSKM } \\
-4.8- \\
(2.5 \%)\end{array}$ & $\begin{array}{c}\text { GARCH } \\
\text { - 8.0- } \\
(\mathbf{4 . 9} \%)\end{array}$ & $\begin{array}{c}\text { RSKM } \\
\text {-6.4 - } \\
\text { (1.6 \%) }\end{array}$ \\
\hline & $\begin{array}{c}\text { GARCH_G } \\
\text { - 2.9- } \\
(\mathbf{4 . 8} \%) \\
\end{array}$ & $\begin{array}{c}\text { GARCH_G } \\
-4.8- \\
(5.7 \%) \\
\end{array}$ & $\begin{array}{c}\text { GJR } \\
-6.4- \\
(\mathbf{1 . 1} \%)\end{array}$ & $\begin{array}{c}\text { GARCH } \\
-7.3- \\
(5.8 \%)\end{array}$ & $\begin{array}{c}\text { RSKM } \\
-1.7- \\
(1.3 \%)\end{array}$ & $\begin{array}{c}\text { GJR } \\
-3.2- \\
(5.7 \%)\end{array}$ & $\begin{array}{c}\text { GJR } \\
-\mathbf{1 . 6 -} \\
(\mathbf{0 . 7} \%)\end{array}$ & $\begin{array}{c}\text { RSKM } \\
-6.4- \\
(4.2 \%)\end{array}$ & $\begin{array}{c}\text { GJR } \\
-4.8- \\
(\mathbf{1 . 0} \%)\end{array}$ \\
\hline & $\begin{array}{c}\text { GJR } \\
-4.3- \\
(\mathbf{4 . 1} \%)\end{array}$ & $\begin{array}{c}\text { GJR } \\
\text { - 3.2- } \\
\mathbf{( 4 . 8 \% )}\end{array}$ & $\begin{array}{c}\text { GARCH_G } \\
\text { - 3.2- } \\
(\mathbf{1 . 1} \%) \\
\end{array}$ & $\begin{array}{c}\text { GJR_G } \\
-5.8- \\
(\mathbf{4 . 4} \%)\end{array}$ & $\begin{array}{c}\text { EGARCH_G } \\
\mathbf{- 8 . 3 -} \\
\mathbf{( 6 . 8} \%) \\
\end{array}$ & $\begin{array}{c}\text { EGARCH_G_ } \\
-4.8- \\
(5.8 \%)\end{array}$ & $\begin{array}{c}\text { EGARCH_G } \\
\text { - 1.6- } \\
(\mathbf{0 . 5} \%) \\
\end{array}$ & $\begin{array}{c}\text { EGARCH_G } \\
\text {-3.2 - } \\
\mathbf{( 2 . 2} \%) \\
\end{array}$ & $\begin{array}{c}\text { GARCH_G } \\
-3.2- \\
\mathbf{( 0 . 8 \% )} \\
\end{array}$ \\
\hline & \begin{tabular}{|c|} 
EGARCH_G \\
$-4.3-$ \\
$(3.6 \%)$ \\
\end{tabular} & \begin{tabular}{|c|} 
EGARCH_G \\
$-1.6-$ \\
$(\mathbf{4 . 0} \%)$ \\
\end{tabular} & $\begin{array}{c}\text { MEDIAN } \\
-3.2- \\
(\mathbf{0 . 7} \%)\end{array}$ & $\begin{array}{c}\text { MEDIAN } \\
-5.8- \\
(4.4 \%)\end{array}$ & $\begin{array}{c}\text { MEDIAN } \\
-3.3- \\
(1.8 \%)\end{array}$ & $\begin{array}{c}\text { GARCH_G } \\
-3.2- \\
(\mathbf{6 . 4} \%)\end{array}$ & $\begin{array}{c}\text { MEDIAN } \\
-1.6- \\
(0.7 \%)\end{array}$ & $\begin{array}{c}\text { GARCH_G } \\
-6.4- \\
(3.9 \%) \\
\end{array}$ & $\begin{array}{c}\text { MEDIAN } \\
-1.6- \\
(\mathbf{0 . 8} \%)\end{array}$ \\
\hline & $\begin{array}{c}\text { MEDIAN } \\
-2.9- \\
(3.9 \%) \\
\end{array}$ & $\begin{array}{c}\text { MEAN } \\
-3.2- \\
(4.5 \%)\end{array}$ & $\begin{array}{c}\text { MEAN } \\
-3.2- \\
(\mathbf{0 . 7} \%)\end{array}$ & $\begin{array}{c}\text { MEAN } \\
\text { - } 5.8- \\
\text { (4.3 \%) }\end{array}$ & $\begin{array}{c}\text { MEAN } \\
-5.0- \\
(3.3 \%) \\
\end{array}$ & $\begin{array}{c}\text { MEDIAN } \\
-3.2- \\
(\mathbf{5 . 6} \%) \\
\end{array}$ & $\begin{array}{c}\text { MEAN } \\
\text { - 1.6- } \\
(\mathbf{0 . 9} \%)\end{array}$ & $\begin{array}{c}\text { MEDIAN } \\
-3.2- \\
(2.9 \%)\end{array}$ & $\begin{array}{c}\text { MEAN } \\
-\mathbf{1 . 6 -} \\
(\mathbf{0 . 7 \%})\end{array}$ \\
\hline & $\begin{array}{c}\text { MEAN } \\
-2.9- \\
(3.7 \%)\end{array}$ & $\begin{array}{c}\text { MEDIAN } \\
-3.2- \\
(\mathbf{4 . 6} \%)\end{array}$ & $\begin{array}{c}\text { GJR_G } \\
-1.6- \\
(\mathbf{0 . 6} \%)\end{array}$ & $\begin{array}{c}\text { RSKM } \\
-7.3- \\
(4.9 \%)\end{array}$ & $\begin{array}{c}\text { GJR_G } \\
-8.3- \\
(6.4 \%)\end{array}$ & $\begin{array}{c}\text { MEAN } \\
-3.2- \\
(5.7 \%)\end{array}$ & $\begin{array}{c}\text { GARCH_G } \\
-1.6- \\
(\mathbf{1 . 2} \%)\end{array}$ & $\begin{array}{c}\text { GJR_G } \\
-3.2- \\
(2.9 \%)\end{array}$ & $\begin{array}{c}\text { EGARCH_G } \\
-\mathbf{1 . 6 -} \\
(\mathbf{0 . 7} \%)\end{array}$ \\
\hline & $\begin{array}{c}\text { GJR_G } \\
-2.9- \\
(3.8 \%)\end{array}$ & $\begin{array}{c}\text { GJR_G } \\
-3.2- \\
(\mathbf{4 . 5} \%)\end{array}$ & $\begin{array}{c}\text { EGARCH_G } \\
-1.6- \\
(\mathbf{0 . 6} \%)\end{array}$ & \begin{tabular}{|c|} 
GARCH_G \\
$-7.3-$ \\
$(5.2 \%)$
\end{tabular} & $\begin{array}{c}\text { GARCH_G } \\
\text { - 8.3- } \\
(\mathbf{6 . 1} \%)\end{array}$ & $\begin{array}{c}\text { GJR_G } \\
-3.2- \\
(5.3 \%)\end{array}$ & $\begin{array}{c}\text { GJR_G } \\
-1.6- \\
(0.3 \%)\end{array}$ & $\begin{array}{c}\text { MEAN } \\
-3.2- \\
(3.0 \%)\end{array}$ & $\begin{array}{c}\text { GJR_G } \\
-1.6- \\
(\mathbf{0 . 8} \%)\end{array}$ \\
\hline & $\begin{array}{c}\text { GARCH_T } \\
-2.9- \\
(\mathbf{4 . 5} \%) \\
\end{array}$ & $\begin{array}{c}\text { GARCH_T } \\
-4.8- \\
(5.2 \%)\end{array}$ & $\begin{array}{c}\text { GARCH_T } \\
-3.2- \\
(\mathbf{0 . 4} \%)\end{array}$ & $\begin{array}{c}\text { EGARCH_T } \\
\text { - 4.4- } \\
(\mathbf{2 . 9} \%) \\
\end{array}$ & $\begin{array}{c}\text { EGARCH_T } \\
\text { - 8.3- } \\
(\mathbf{6 . 6} \%)\end{array}$ & $\begin{array}{c}\text { EGARCH_T } \\
-3.2- \\
\mathbf{( 4 . 4} \% \mathbf{)}\end{array}$ & $\begin{array}{c}\text { EGARCH_T } \\
\mathbf{- 1 . 6 -} \\
(\mathbf{0 . 0} \%)\end{array}$ & \begin{tabular}{|c|} 
EGARCH_T \\
$-3.2-$ \\
$(\mathbf{1 . 5} \%)$ \\
\end{tabular} & $\begin{array}{c}\text { GJR_T } \\
-1.6- \\
(\mathbf{0 . 6 \% )} \\
\end{array}$ \\
\hline & $\begin{array}{c}\text { GJR_T } \\
-2.9- \\
(3.5 \%) \\
\end{array}$ & \begin{tabular}{|c|} 
EGARCH_T \\
$-\mathbf{1 . 6 -}$ \\
$(\mathbf{3 . 9} \%)$ \\
\end{tabular} & $\begin{array}{c}\text { GJR_T } \\
-1.6- \\
(\mathbf{0 . 3} \%) \\
\end{array}$ & $\begin{array}{c}\text { GJR_T } \\
\text { - } 5.8- \\
(3.8 \%) \\
\end{array}$ & $\begin{array}{c}\text { GJR_T } \\
\mathbf{- 6 . 6 -} \\
(\mathbf{4 . 3} \%) \\
\end{array}$ & $\begin{array}{c}\text { GARCH_T } \\
-3.2- \\
(5.8 \%) \\
\end{array}$ & $\begin{array}{c}\text { GARCH_T } \\
-\mathbf{1 . 6 -} \\
(\mathbf{0 . 6} \%) \\
\end{array}$ & $\begin{array}{c}\text { GJR_T } \\
-3.2- \\
(2.1 \%) \\
\end{array}$ & $\begin{array}{c}\text { EGARCH_T } \\
-1.6- \\
(\mathbf{0 . 5} \%) \\
\end{array}$ \\
\hline & \begin{tabular}{|c|} 
EGARCH_T \\
$-1.4-$ \\
$(\mathbf{1 . 3} \%)$ \\
\end{tabular} & $\begin{array}{c}\text { GJR_T } \\
-3.2- \\
(4.2 \%)\end{array}$ & $\begin{array}{c}\text { EGARCH_T } \\
-1.6- \\
(\mathbf{0 . 3} \%) \\
\end{array}$ & $\begin{array}{c}\text { GARCH_T } \\
-5.8- \\
(4.3 \%)\end{array}$ & $\begin{array}{c}\text { GARCH_T } \\
\text { - 8.3- } \\
(\mathbf{6 . 8} \%)\end{array}$ & $\begin{array}{c}\text { GJR_T } \\
-3.2- \\
(\mathbf{4 . 6} \%)\end{array}$ & $\begin{array}{c}\text { GJR_T } \\
-\mathbf{0 . 0 -} \\
(\mathbf{0 . 0} \%)\end{array}$ & $\begin{array}{c}\text { GARCH_T } \\
-3.2- \\
(2.9 \%)\end{array}$ & $\begin{array}{c}\text { GARCH_T } \\
-1.6- \\
(\mathbf{0 . 2} \%)\end{array}$ \\
\hline & $\begin{array}{c}\text { INF } \\
-1.4- \\
(1.3 \%)\end{array}$ & $\begin{array}{c}\text { INF } \\
-1.6- \\
(3.9 \%)\end{array}$ & $\begin{array}{c}\text { INF } \\
-1.6- \\
(0.3 \%)\end{array}$ & $\begin{array}{c}\text { INF } \\
-4.4- \\
(2.1 \%)\end{array}$ & $\begin{array}{c}\text { INF } \\
-5.0- \\
(2.7 \%)\end{array}$ & $\begin{array}{c}\text { INF } \\
-3.2- \\
(4.4 \%)\end{array}$ & $\begin{array}{c}\text { INF } \\
-0.0- \\
(0.0 \%)\end{array}$ & $\begin{array}{c}\text { INF } \\
-3.2- \\
(\mathbf{1 . 5} \%)\end{array}$ & $\begin{array}{c}\text { INF } \\
-1.6- \\
(0.2 \%)\end{array}$ \\
\hline
\end{tabular}

Notes: Higher in the table means lower daily capital charges. The number of violations NoV is the middle number in each cell, while the lower number is the accumulated losses. Underscore T ( $T$ ) denotes Student-t distribution and underscore G $(G)$ denotes Generalized Normal distribution. 
Table 5b. Daily Capital Charges Rankings - During GFC

\begin{tabular}{|c|c|c|c|c|c|c|c|c|c|}
\hline & CAC & DAX & DJ & FTSE & HSHK & IBEX & NIKKEI & SMI & SP500 \\
\hline & $\begin{array}{c}\text { SUP } \\
-13.06- \\
(7.3 \%)\end{array}$ & $\begin{array}{c}\text { EGARCH } \\
\mathbf{- 8 . 4 -} \\
\mathbf{( 3 . 9 \% )}\end{array}$ & $\begin{array}{c}\text { EGARCH_G } \\
-6.7- \\
(\mathbf{6 . 7 \% )}\end{array}$ & $\begin{array}{c}\text { SUP } \\
-13.3- \\
(8.0 \%)\end{array}$ & $\begin{array}{c}\text { SUP } \\
-4.8- \\
(4.6 \%)\end{array}$ & $\begin{array}{c}\text { SUP } \\
-10- \\
(2.5 \%)\end{array}$ & $\begin{array}{c}\text { EGARCH } \\
\mathbf{- 1 4 . 9 -} \\
(\mathbf{1 3 . 0 \% )}\end{array}$ & $\begin{array}{c}\text { EGARCH } \\
\text {-8.3- } \\
(\mathbf{8 . 0 \% )}\end{array}$ & $\begin{array}{c}\text { EGARCH } \\
-\mathbf{1 6 . 7 -} \\
(\mathbf{1 2 . 2 \% )}\end{array}$ \\
\hline & $\begin{array}{c}\text { EGARCH } \\
-7.5- \\
(\mathbf{4 . 6 \% )}\end{array}$ & $\begin{array}{c}\text { GARCH } \\
\text {-8.4- } \\
(\mathbf{3 . 9 \% )}\end{array}$ & $\begin{array}{c}\text { EGARCH } \\
-\mathbf{- 1 1 . 7 -} \\
(\mathbf{6 . 7 \% )}\end{array}$ & $\begin{array}{c}\text { EGARCH } \\
\mathbf{- 1 3 . 3 -} \\
(\mathbf{8 . 0 \% )}\end{array}$ & $\begin{array}{c}\text { EGARCH } \\
-4.8- \\
(\mathbf{4 . 6 \% )}\end{array}$ & $\begin{array}{c}\text { EGARCH_G } \\
-3- \\
(2.5 \%)\end{array}$ & $\begin{array}{c}\text { SUP } \\
-18.2- \\
(13.0 \%)\end{array}$ & $\begin{array}{c}\text { SUP } \\
-11.7- \\
(\mathbf{8 . 0 \% )}\end{array}$ & $\begin{array}{c}\text { SUP } \\
-18.3- \\
(12.5 \%)\end{array}$ \\
\hline & $\begin{array}{c}\text { EGARCH_G } \\
-7.5- \\
(\mathbf{5 . 7 \% )} \\
\end{array}$ & $\begin{array}{c}\text { EGARCH_G } \\
\mathbf{- 8 . 4 -} \\
(\mathbf{2 . 8 \% )} \\
\end{array}$ & $\begin{array}{c}\text { GARCH } \\
-\mathbf{1 0 . 0 -} \\
\mathbf{( 5 . 0 \% )}\end{array}$ & \begin{tabular}{|c|} 
EGARCH_G \\
$\mathbf{- 1 3 . 3 -}$ \\
$(\mathbf{6 . 6 \% )}$ \\
\end{tabular} & $\begin{array}{c}\text { GJR_N } \\
-4.8- \\
(4.2 \%)\end{array}$ & $\begin{array}{c}\text { EGARCH } \\
-\mathbf{1 0 -} \\
\mathbf{( 4 . 4 \% )} \\
\end{array}$ & $\begin{array}{c}\text { RSKM } \\
-6.6- \\
(9.8 \%)\end{array}$ & \begin{tabular}{|c|} 
EGARCH_G \\
$\mathbf{- 8 . 3 -}$ \\
$\mathbf{( 4 . 2 \% )}$ \\
\end{tabular} & $\begin{array}{c}\text { GJR } \\
\mathbf{- 6 . 7 -} \\
\mathbf{( 5 . 2 \% )}\end{array}$ \\
\hline & $\begin{array}{c}\text { GJR } \\
-7.5- \\
(5.1 \%)\end{array}$ & $\begin{array}{c}\text { GJR } \\
\mathbf{- 8 . 4 -} \\
(\mathbf{4 . 2 \% )}\end{array}$ & $\begin{array}{c}\text { GJR } \\
-6.7- \\
(3.9 \%)\end{array}$ & $\begin{array}{c}\text { GJR } \\
-9.5- \\
(6.5 \%)\end{array}$ & $\begin{array}{c}\text { GARCH } \\
-4.8- \\
(5.5 \%)\end{array}$ & $\begin{array}{c}\text { GJR } \\
\mathbf{- 8 . 1 -} \\
\mathbf{( 3 . 5 \% )}\end{array}$ & $\begin{array}{c}\text { GARCH } \\
\text {-8.3- } \\
(\mathbf{8 . 1 \% )}\end{array}$ & $\begin{array}{c}\text { GJR } \\
\mathbf{- 8 . 3 -} \\
(\mathbf{5 . 1 \% )}\end{array}$ & $\begin{array}{c}\text { MEDIAN } \\
-5.0- \\
(4.9 \%)\end{array}$ \\
\hline & $\begin{array}{c}\text { EGARCH_T } \\
-3.7- \\
(\mathbf{3 . 3 \% )} \\
\end{array}$ & $\begin{array}{c}\text { SUP } \\
-15.1- \\
(6.5 \%) \\
\end{array}$ & $\begin{array}{c}\text { SUP } \\
-15.0- \\
(7.5 \%)\end{array}$ & \begin{tabular}{|c|} 
EGARCH_T \\
$\mathbf{- 1 1 . 4 -}$ \\
$\mathbf{( 4 . 3 \% )}$ \\
\end{tabular} & $\begin{array}{c}\text { RSKM } \\
-4.8- \\
(5.4 \%)\end{array}$ & $\begin{array}{c}\text { GARCH } \\
-8.1- \\
(\mathbf{2 . 6 \% )}\end{array}$ & $\begin{array}{c}\text { EGARCH_G } \\
-9.9- \\
(\mathbf{6 . 7 \% )} \\
\end{array}$ & $\begin{array}{c}\text { GARCH } \\
-10- \\
(\mathbf{4 . 8 \% )}\end{array}$ & $\begin{array}{c}\text { MEAN } \\
-5.0- \\
(\mathbf{4 . 6 \% )} \\
\end{array}$ \\
\hline & $\begin{array}{c}\text { GARCH } \\
-9.3- \\
(3.9 \%)\end{array}$ & $\begin{array}{c}\text { MEDIAN } \\
-6.7- \\
(2.7 \%)\end{array}$ & $\begin{array}{c}\text { MEDIAN } \\
-3.3- \\
(3.0 \%)\end{array}$ & $\begin{array}{c}\text { GARCH } \\
-7.6- \\
(\mathbf{6 . 3} \%)\end{array}$ & $\begin{array}{c}\text { EGARCH_G } \\
\mathbf{- 1 . 6 -} \\
(\mathbf{1 . 0 \% )}\end{array}$ & $\begin{array}{c}\text { RSKM } \\
-5.0- \\
(2.7 \%)\end{array}$ & $\begin{array}{c}\text { GJR_N } \\
-9.9- \\
(5.5 \%)\end{array}$ & $\begin{array}{c}\text { MEDIAN } \\
-6.7- \\
(3.7 \%)\end{array}$ & $\begin{array}{c}\text { EGARCH_T } \\
-3.3- \\
\mathbf{( 4 . 6 \% )}\end{array}$ \\
\hline 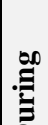 & $\begin{array}{c}\text { MEDIAN } \\
-5.6- \\
(3.5 \%)\end{array}$ & $\begin{array}{c}\text { MEAN } \\
-6.7- \\
(2.7 \%)\end{array}$ & $\begin{array}{c}\text { MEAN } \\
-5.0- \\
(\mathbf{2 . 8 \% )}\end{array}$ & $\begin{array}{c}\text { MEAN } \\
-9.5- \\
(4.9 \%)\end{array}$ & $\begin{array}{c}\text { MEDIAN } \\
-4.8- \\
(1.9 \%)\end{array}$ & $\begin{array}{c}\text { MEDIAN } \\
-5.0- \\
(1.6 \%)\end{array}$ & $\begin{array}{c}\text { MEDIAN } \\
-5.0- \\
(\mathbf{4 . 8 \% )}\end{array}$ & $\begin{array}{c}\text { MEAN } \\
-6.7- \\
(3.6 \%)\end{array}$ & $\begin{array}{c}\text { GARCH } \\
-\mathbf{1 1 . 7 -} \\
\mathbf{( 7 . 5 \% )}\end{array}$ \\
\hline & $\begin{array}{c}\text { MEAN } \\
-5.6- \\
(3.3 \%)\end{array}$ & $\begin{array}{c}\text { GJR_G } \\
-\mathbf{8 . 4 -} \\
(3.3 \%)\end{array}$ & $\begin{array}{c}\text { GARCH_G } \\
-3.3- \\
(\mathbf{2 . 5 \% )}\end{array}$ & $\begin{array}{c}\text { GJR_G } \\
-9.5- \\
(5.6 \%)\end{array}$ & $\begin{array}{c}\text { MEAN } \\
-4.8- \\
(\mathbf{1 . 4 \% )}\end{array}$ & $\begin{array}{c}\text { GJR_G } \\
-5.0- \\
(\mathbf{1 . 9} \%)\end{array}$ & $\begin{array}{c}\text { MEAN } \\
-5.0- \\
(4.9 \%)\end{array}$ & $\begin{array}{c}\text { GJR_G } \\
-8.3- \\
(4.0 \%)\end{array}$ & $\begin{array}{c}\text { EGARCH_G } \\
-13.3- \\
(\mathbf{7 . 2 \% )}\end{array}$ \\
\hline & $\begin{array}{c}\text { RSKM } \\
-1.8- \\
(3.2 \%)\end{array}$ & $\begin{array}{c}\text { GARCH_G } \\
-5.0- \\
(\mathbf{2 . 7 \% )}\end{array}$ & $\begin{array}{c}\text { GJR_G } \\
-3.3- \\
(2.5 \%)\end{array}$ & $\begin{array}{c}\text { RSKM } \\
-9.5- \\
(6.0 \%)\end{array}$ & $\begin{array}{c}\text { GJR_G } \\
-3.2- \\
(\mathbf{1 . 0 \% )}\end{array}$ & $\begin{array}{c}\text { MEAN } \\
-3.0- \\
(\mathbf{1 . 5 \% )}\end{array}$ & $\begin{array}{c}\text { GARCH_G } \\
-5.0- \\
(\mathbf{6 . 3 \% )}\end{array}$ & \begin{tabular}{|c|} 
EGARCH_T \\
$\mathbf{- 6 . 7 -}$ \\
$\mathbf{( 2 . 8 \% )}$
\end{tabular} & $\begin{array}{c}\text { GJR_G } \\
-5.0- \\
(\mathbf{4 . 0} \%)\end{array}$ \\
\hline & $\begin{array}{c}\text { GJR_G } \\
-7.5- \\
(\mathbf{4 . 4 \% )}\end{array}$ & $\begin{array}{c}\text { GJR_T } \\
-6.7- \\
(2.5 \%)\end{array}$ & $\begin{array}{c}\text { EGARCH_T } \\
-3.3- \\
(\mathbf{2 . 6 \% )}\end{array}$ & $\begin{array}{c}\text { MEDIAN } \\
-11.4- \\
(5.4 \%)\end{array}$ & $\begin{array}{c}\text { GARCH_G } \\
-4.8- \\
(2.5 \%)\end{array}$ & $\begin{array}{c}\text { GARCH_G } \\
-3.0- \\
(\mathbf{1 . 3 \% )}\end{array}$ & $\begin{array}{c}\text { GJR_G } \\
-3.3- \\
\mathbf{( 3 . 8 \% )}\end{array}$ & $\begin{array}{c}\text { GARCH_G } \\
\mathbf{- 8 . 3 -} \\
\mathbf{( 3 . 3 \% )}\end{array}$ & $\begin{array}{c}\text { GARCH_G } \\
\mathbf{- 8 . 3 -} \\
\mathbf{( 4 . 5 \% )}\end{array}$ \\
\hline & $\begin{array}{c}\text { GARCH_G } \\
-5.6- \\
(\mathbf{2 . 7 \% )}\end{array}$ & $\begin{array}{c}\text { EGARCH_T } \\
-3.4- \\
(\mathbf{1 . 9 \% )}\end{array}$ & $\begin{array}{l}\text { RSKM } \\
-10.0- \\
(4.3 \%) \\
\end{array}$ & $\begin{array}{c}\text { GARCH_G } \\
-7.6- \\
\mathbf{( 5 . 0 \% )}\end{array}$ & $\begin{array}{c}\text { EGARCH_T } \\
-\mathbf{0 . 0 -} \\
(\mathbf{0 . 0 \% )} \\
\end{array}$ & $\begin{array}{c}\text { EGARCH_T } \\
-3.0- \\
(\mathbf{0 . 6 \% )}\end{array}$ & \begin{tabular}{|c|} 
EGARCH_T \\
$\mathbf{- 8 . 3 -}$ \\
$\mathbf{( 3 . 0 \% )}$ \\
\end{tabular} & $\begin{array}{c}\text { GJR_T } \\
-6.7- \\
(2.3 \%)\end{array}$ & $\begin{array}{c}\text { RSKM } \\
-10.0- \\
(6.2 \%) \\
\end{array}$ \\
\hline & $\begin{array}{c}\text { GJR_T } \\
-5.6- \\
(3.3 \%)\end{array}$ & $\begin{array}{c}\text { RSKM } \\
-8.4- \\
(3.7 \%)\end{array}$ & $\begin{array}{c}\text { GJR_T } \\
-3.3- \\
(\mathbf{1 . 4 \% )}\end{array}$ & $\begin{array}{c}\text { GJR_T } \\
-\mathbf{9 . 5 -} \\
(\mathbf{4 . 1 \% )}\end{array}$ & $\begin{array}{c}\text { GJR_T } \\
-0.0- \\
(\mathbf{0 . 0 \% )}\end{array}$ & $\begin{array}{c}\text { GJR_T } \\
-2.0- \\
(\mathbf{0 . 2 \% )}\end{array}$ & $\begin{array}{c}\text { GJR_T } \\
-3.3- \\
(2.8 \%)\end{array}$ & $\begin{array}{c}\text { RSKM } \\
-10.0- \\
(5.8 \%)\end{array}$ & $\begin{array}{c}\text { GJR_T } \\
-3.3- \\
(3.0 \%)\end{array}$ \\
\hline & $\begin{array}{c}\text { GARCH_T } \\
\text {-1.9- } \\
(\mathbf{1 . 9 \% )}\end{array}$ & $\begin{array}{c}\text { GARCH_T } \\
-5.0- \\
(\mathbf{1 . 7 \% )}\end{array}$ & $\begin{array}{c}\text { GARCH_T } \\
\text {-3.3- } \\
(\mathbf{1 . 2 \% )}\end{array}$ & $\begin{array}{c}\text { GARCH_T } \\
-5.7- \\
(3.1 \%)\end{array}$ & $\begin{array}{c}\text { GARCH_T } \\
-0.0- \\
(\mathbf{0 . 0 \% )}\end{array}$ & $\begin{array}{c}\text { GARCH_T } \\
-2.0- \\
(\mathbf{0 . 1 \% )}\end{array}$ & $\begin{array}{c}\text { GARCH_T } \\
-5.0- \\
(\mathbf{4 . 3 \% )}\end{array}$ & $\begin{array}{c}\text { GARCH_T } \\
\text {-1.7- } \\
(\mathbf{1 . 6 \% )}\end{array}$ & $\begin{array}{c}\text { GARCH_T } \\
-3.3- \\
(\mathbf{2 . 9 \% )}\end{array}$ \\
\hline & $\begin{array}{c}\text { INF } \\
-1.9- \\
(\mathbf{1 . 9 \% )}\end{array}$ & $\begin{array}{c}\text { INF } \\
-3.4- \\
(\mathbf{1 . 7 \% )}\end{array}$ & $\begin{array}{c}\text { INF } \\
-3.3- \\
(\mathbf{1 . 2 \% )}\end{array}$ & $\begin{array}{c}\text { INF } \\
-5.7- \\
(\mathbf{1 . 4 \% )}\end{array}$ & $\begin{array}{c}\text { INF } \\
-0.0- \\
(\mathbf{0 . 0 \% )}\end{array}$ & $\begin{array}{c}\text { INF } \\
-0.0- \\
(\mathbf{0 . 0 \% )}\end{array}$ & $\begin{array}{c}\text { INF } \\
-3.3- \\
(\mathbf{2 . 3 \% )}\end{array}$ & $\begin{array}{c}\text { INF } \\
-1.7- \\
(\mathbf{0 . 7 \% )}\end{array}$ & $\begin{array}{c}\text { INF } \\
-3.3- \\
(2.7 \%)\end{array}$ \\
\hline
\end{tabular}


Table 5c. Daily Capital Charges Rankings - After GFC

\begin{tabular}{|c|c|c|c|c|c|c|c|c|c|}
\hline & CAC & $A X$ & $\mathbf{J}$ & TSE & ISHK & BEX & JIKEEI & SMI & SP500 \\
\hline \multirow{14}{*}{$\underbrace{}_{\mathbb{E}}$} & $\begin{array}{c}\text { SUP } \\
-7.8- \\
(7.5 \%)\end{array}$ & $\begin{array}{c}\text { SUP } \\
-6.6- \\
(7.05 \%)\end{array}$ & $\begin{array}{c}\text { SUP } \\
-9.0- \\
(6.52 \%)\end{array}$ & $\begin{array}{c}\text { SUP } \\
-9.5- \\
(5.74 \%)\end{array}$ & $\begin{array}{c}\text { SUP } \\
-2.4- \\
(2.98 \%)\end{array}$ & $\begin{array}{c}\text { SUP } \\
-8.4- \\
(\mathbf{1 0 . 6 \% )}\end{array}$ & $\begin{array}{c}\text { GARCH } \\
-3.6- \\
(2.78 \%)\end{array}$ & $\begin{array}{c}\text { SUP } \\
-6.59- \\
(4.01 \%)\end{array}$ & $\begin{array}{c}\text { SUP } \\
-10.8- \\
(8.74 \%)\end{array}$ \\
\hline & $\begin{array}{c}\text { GJR } \\
-4.8- \\
(\mathbf{4 . 2 \% )}\end{array}$ & $\begin{array}{c}\text { EGARCH } \\
-4.8- \\
\mathbf{( 5 . 7 6 \% )}\end{array}$ & $\begin{array}{c}\text { EGARCH } \\
\mathbf{- 9 . 0 -} \\
\mathbf{( 5 . 6 3 \% )}\end{array}$ & $\begin{array}{c}\text { MEAN } \\
-4.2- \\
(\mathbf{1 . 9 4 \% )}\end{array}$ & $\begin{array}{c}\text { GJR } \\
-1.8- \\
(2.36 \%)\end{array}$ & $\begin{array}{c}\text { EGARCH } \\
-7.8- \\
(\mathbf{8 . 7 \% )}\end{array}$ & $\begin{array}{c}\text { SUP } \\
-6.6- \\
(4.91 \%)\end{array}$ & $\begin{array}{c}\text { GARCH } \\
-4.2- \\
(2.41 \%)\end{array}$ & $\begin{array}{c}\text { EGARCH } \\
\mathbf{- 1 0 . 2 -} \\
\mathbf{( 7 . 4 9 \% )}\end{array}$ \\
\hline & $\begin{array}{c}\text { EGARCH } \\
\text {-6.0- } \\
\mathbf{( 4 . 9 \% )}\end{array}$ & $\begin{array}{c}\text { GARCH } \\
-4.2- \\
(\mathbf{3 . 1 2 \% )}\end{array}$ & $\begin{array}{c}\text { GARCH } \\
-5.4- \\
(3.72 \%)\end{array}$ & $\begin{array}{c}\text { EGARCH } \\
-7.1- \\
(\mathbf{3 . 9 8 \% )}\end{array}$ & $\begin{array}{c}\text { EGARCH } \\
\mathbf{- 1 . 8 -} \\
\mathbf{( 1 . 5 7 \% )}\end{array}$ & $\begin{array}{c}\text { GARCH } \\
-4.8- \\
(\mathbf{7 . 0 \% )}\end{array}$ & $\begin{array}{c}\text { GJR } \\
\mathbf{- 4 . 8 -} \\
\mathbf{( 3 . 6 4 \% )}\end{array}$ & $\begin{array}{c}\text { GJR } \\
-5.4- \\
(2.47 \%)\end{array}$ & $\begin{array}{c}\text { EGARCH_G_G } \\
-6.6- \\
\mathbf{( 4 . 9 2 \% )}\end{array}$ \\
\hline & $\begin{array}{c}\text { EGARCH_G } \\
\text {-4.2- } \\
\mathbf{( 3 . 9 \% )}\end{array}$ & $\begin{array}{c}\text { EGARCH_G } \\
-4.2- \\
\mathbf{( 4 . 7 3 \% )}\end{array}$ & $\begin{array}{c}\text { GJR } \\
-7.2- \\
(\mathbf{4 . 0 2 \% )}\end{array}$ & \begin{tabular}{|c|} 
EGARCH_T \\
$-4.2-$ \\
$(\mathbf{2 . 0 9 \% )}$
\end{tabular} & $\begin{array}{c}\text { GARCH } \\
-2.4- \\
(2.76 \%)\end{array}$ & $\begin{array}{c}\text { MEDIAN } \\
-3.6- \\
(4.9 \%)\end{array}$ & $\begin{array}{c}\text { EGARCH } \\
-4.8- \\
(\mathbf{3 . 0 9 \% )}\end{array}$ & $\begin{array}{c}\text { EGARCH } \\
-4.8- \\
(\mathbf{1 . 8 5 \% )}\end{array}$ & $\begin{array}{c}\text { GARCH } \\
-7.2- \\
(\mathbf{4 . 2 0 \% )}\end{array}$ \\
\hline & $\begin{array}{c}\text { MEDIAN } \\
-3.0- \\
(\mathbf{2 . 8 \% )}\end{array}$ & $\begin{array}{c}\text { MEDIAN } \\
-4.2- \\
(3.58 \%)\end{array}$ & $\begin{array}{c}\text { RSKM } \\
-6.0- \\
(4.25 \%)\end{array}$ & $\begin{array}{c}\text { MEDIAN } \\
-4.8- \\
(2.37 \%)\end{array}$ & $\begin{array}{c}\text { RSKM } \\
-2.4- \\
(2.89 \%)\end{array}$ & $\begin{array}{c}\text { RSKM } \\
-4.2- \\
(6.6 \%)\end{array}$ & $\begin{array}{c}\text { RSKM } \\
-5.4 \text { - } \\
(3.17 \%)\end{array}$ & $\begin{array}{c}\text { GJR_G } \\
-3.60- \\
(\mathbf{1 . 6 7 \% )}\end{array}$ & $\begin{array}{c}\text { MEDIAN } \\
-4.8- \\
(2.73 \%)\end{array}$ \\
\hline & $\begin{array}{c}\text { GJR_G } \\
-4.2- \\
\mathbf{( 3 . 3 \% )}\end{array}$ & $\begin{array}{c}\text { RSKM } \\
-4.2- \\
(\mathbf{2 . 1 0} \%)\end{array}$ & $\begin{array}{c}\text { EGARCH_G } \\
-7.2- \\
\mathbf{( 3 . 3 8 \% )}\end{array}$ & $\begin{array}{c}\text { GARCH } \\
-5.3- \\
(2.72 \%)\end{array}$ & $\begin{array}{c}\text { GJR_G } \\
-0.6- \\
(1.43 \%)\end{array}$ & \begin{tabular}{|c|} 
EGARCH_G \\
$-6.0-$ \\
$(\mathbf{6 . 0} \%)$
\end{tabular} & $\begin{array}{c}\text { MEDIAN } \\
-2.4- \\
(1.01 \%)\end{array}$ & $\begin{array}{c}\text { EGARCH_G } \\
-3.60- \\
(\mathbf{1 . 1 8 \% )}\end{array}$ & $\begin{array}{c}\text { GJR } \\
-\mathbf{8 . 4 -} \\
(\mathbf{5 . 1 0} \%)\end{array}$ \\
\hline & $\begin{array}{c}\text { MEAN } \\
-3.6- \\
(2.4 \%)\end{array}$ & $\begin{array}{c}\text { GJR_N } \\
-5.4- \\
(5.50 \%)\end{array}$ & $\begin{array}{c}\text { MEDIAN } \\
-4.8- \\
(2.39 \%)\end{array}$ & $\begin{array}{c}\text { GJR_N } \\
-6.5- \\
(4.11 \%)\end{array}$ & $\begin{array}{c}\text { MEDIAN } \\
-0.6- \\
(1.40 \%)\end{array}$ & $\begin{array}{c}\text { GJR_G } \\
-4.8- \\
(4.6 \%)\end{array}$ & \begin{tabular}{|c|} 
EGARCH_G \\
$-2.4-$ \\
$\mathbf{( 1 . 3 4 \% )}$ \\
\end{tabular} & $\begin{array}{c}\text { RSKM } \\
-3.60- \\
(2.51 \%)\end{array}$ & $\begin{array}{c}\text { MEAN } \\
-4.8- \\
(\mathbf{2 . 6 3 \% )}\end{array}$ \\
\hline & \begin{tabular}{|c|} 
EGARCH_T \\
$-3.6-$ \\
$(\mathbf{2 . 9 \% )}$
\end{tabular} & $\begin{array}{c}\text { MEAN } \\
-4.2- \\
(\mathbf{2 . 9 5} \%)\end{array}$ & $\begin{array}{c}\text { GJR_G } \\
-4.8- \\
(2.21 \%)\end{array}$ & $\begin{array}{c}\text { GARCH_G } \\
-3.0- \\
(\mathbf{1 . 8 2 \% )}\end{array}$ & $\begin{array}{c}\text { MEAN } \\
\mathbf{- 0 . 6 -} \\
(\mathbf{1 . 3 1 \% )}\end{array}$ & $\begin{array}{c}\text { MEAN } \\
-3.6- \\
(4.7 \%)\end{array}$ & $\begin{array}{c}\text { MEAN } \\
\text {-1.8- } \\
(\mathbf{1 . 0 0 \% )}\end{array}$ & $\begin{array}{c}\text { MEDIAN } \\
-3.00- \\
(1.12 \%)\end{array}$ & $\begin{array}{c}\text { RSKM } \\
-6.6- \\
(4.19 \%)\end{array}$ \\
\hline & $\begin{array}{c}\text { GARCH } \\
\mathbf{- 5 . 4 -} \\
(\mathbf{4 . 1 \% )}\end{array}$ & $\begin{array}{c}\text { GJR_G } \\
-4.8- \\
(4.32 \%)\end{array}$ & $\begin{array}{c}\text { MEAN } \\
-4.8- \\
(\mathbf{2 . 2 0 \% )}\end{array}$ & $\begin{array}{c}\text { RSKM } \\
-4.2- \\
(2.43 \%)\end{array}$ & $\begin{array}{c}\text { EGARCH_G } \\
-\mathbf{0 . 6 -} \\
\mathbf{( 0 . 9 8 \% )}\end{array}$ & $\begin{array}{c}\text { GJR_N } \\
-7.2- \\
(7.1 \%)\end{array}$ & \begin{tabular}{|c|} 
GARCH_G \\
$-2.4-$ \\
$(\mathbf{0 . 9 7 \% )}$
\end{tabular} & $\begin{array}{c}\text { MEAN } \\
-3.00- \\
(\mathbf{1 . 0 3 \% )}\end{array}$ & $\begin{array}{c}\text { GJR_G } \\
-4.8- \\
(2.74 \%)\end{array}$ \\
\hline & $\begin{array}{c}\text { RSKM } \\
-4.2- \\
(\mathbf{4 . 3 \% )}\end{array}$ & $\begin{array}{c}\text { GJR_T } \\
-4.2- \\
(\mathbf{3 . 2 6 \% )}\end{array}$ & \begin{tabular}{|c|} 
EGARCH_T \\
$-3.00-$ \\
$\mathbf{( 1 . 5 9 \% )}$
\end{tabular} & $\begin{array}{c}\text { EGARCH_G } \\
\text {-5.9- } \\
(\mathbf{3 . 1 3 \% )}\end{array}$ & $\begin{array}{c}\text { GARCH_G } \\
\text {-1.2- } \\
\mathbf{( 1 . 5 1 \% )}\end{array}$ & $\begin{array}{c}\text { GARCH_G } \\
-3.6- \\
(5.1 \%)\end{array}$ & $\begin{array}{c}\text { GJR_G } \\
-3.00- \\
(\mathbf{1 . 1 1 \% )}\end{array}$ & $\begin{array}{c}\text { GARCH_G } \\
-3.00- \\
(\mathbf{1 . 4 9 \% )}\end{array}$ & $\begin{array}{c}\text { GARCH_G } \\
-3.6- \\
(\mathbf{1 . 9 3 \% )}\end{array}$ \\
\hline & $\begin{array}{c}\text { GJR_T } \\
-3.0- \\
(\mathbf{2 . 1 \% )}\end{array}$ & $\begin{array}{c}\text { GARCH_G } \\
-3.6- \\
(\mathbf{1 . 5 1 \% )}\end{array}$ & $\begin{array}{c}\text { GARCH_G } \\
-4.2- \\
\mathbf{( 1 . 9 7 \% )}\end{array}$ & $\begin{array}{c}\text { GJR_T } \\
-3.6- \\
(2.31 \%)\end{array}$ & $\begin{array}{c}\text { GJR_T } \\
\mathbf{- 0 . 6 -} \\
(\mathbf{0 . 9 9 \% )}\end{array}$ & $\begin{array}{c}\text { GJR_T } \\
-3.0- \\
(2.0 \%)\end{array}$ & $\begin{array}{c}\text { GJR_T } \\
\text {-1.2- } \\
(\mathbf{0 . 3 2 \% )}\end{array}$ & \begin{tabular}{|c|} 
EGARCH_T \\
$-1.2-$ \\
$(\mathbf{0 . 5 4 \% )}$
\end{tabular} & $\begin{array}{c}\text { EGARCH_T } \\
-5.4- \\
(\mathbf{2 . 4 4 \% )}\end{array}$ \\
\hline & $\begin{array}{c}\text { GARCH_G } \\
-3.6- \\
(\mathbf{2 . 5 \% )}\end{array}$ & $\begin{array}{c}\text { EGARCH_T } \\
-4.2- \\
\mathbf{( 3 . 5 6 \% )}\end{array}$ & $\begin{array}{c}\text { GJR_T } \\
-3.00- \\
(\mathbf{0 . 7 2 \% )}\end{array}$ & $\begin{array}{c}\text { GJR_G } \\
-6.5- \\
(3.27 \%)\end{array}$ & $\begin{array}{c}\text { EGARCH_T } \\
-\mathbf{0 . 6 -} \\
\mathbf{( 0 . 4 6 \% )}\end{array}$ & $\begin{array}{c}\text { EGARCH_T } \\
-4.2- \\
(\mathbf{2 . 5 \% )}\end{array}$ & \begin{tabular}{|c|} 
EGARCH_T \\
$-1.2-$ \\
$(\mathbf{0 . 3 5 \% )}$
\end{tabular} & $\begin{array}{c}\text { GJR_T } \\
-1.8- \\
(\mathbf{0 . 8 0 \% )}\end{array}$ & $\begin{array}{c}\text { GJR_T } \\
-3.0- \\
(1.33 \%)\end{array}$ \\
\hline & $\begin{array}{c}\text { GARCH_T } \\
-1.8- \\
(\mathbf{1 . 0 \% )}\end{array}$ & $\begin{array}{c}\text { GARCH_T } \\
-1.8- \\
(\mathbf{0 . 3 1 \% )}\end{array}$ & $\begin{array}{c}\text { GARCH_T } \\
-1.2- \\
(\mathbf{0 . 6 9 \% )}\end{array}$ & $\begin{array}{c}\text { GARCH_T } \\
-1.8- \\
(\mathbf{0 . 9 2 \% )}\end{array}$ & $\begin{array}{c}\text { GARCH_T } \\
-\mathbf{0 . 6 -} \\
(\mathbf{0 . 8 3 \% )}\end{array}$ & $\begin{array}{c}\text { GARCH_T } \\
-2.4- \\
(\mathbf{2 . 9 \% )}\end{array}$ & \begin{tabular}{|c|} 
GARCH_T \\
$\mathbf{- 0 . 6 -}$ \\
$\mathbf{( 0 . 4 9 \% )}$
\end{tabular} & $\begin{array}{c}\text { GARCH_T } \\
-1.2- \\
(\mathbf{0 . 4 9 \% )}\end{array}$ & $\begin{array}{c}\text { GARCH_T } \\
-1.2- \\
(\mathbf{0 . 5 9 \% )}\end{array}$ \\
\hline & $\begin{array}{c}\text { INF } \\
-1.2- \\
(\mathbf{1 . 0 \% )}\end{array}$ & $\begin{array}{c}\text { INF } \\
-1.8- \\
(\mathbf{0 . 2 7 \% )}\end{array}$ & $\begin{array}{c}\text { INF } \\
-1.2- \\
(\mathbf{0 . 4 6 \% )}\end{array}$ & $\begin{array}{c}\text { INF } \\
-1.2- \\
(\mathbf{0 . 7 7 \% )}\end{array}$ & $\begin{array}{c}\text { INF } \\
-0.6- \\
(\mathbf{0 . 4 6 \% )})\end{array}$ & $\begin{array}{c}\text { INF } \\
-1.8- \\
(\mathbf{1 . 8 \% )}\end{array}$ & $\begin{array}{c}\text { INF } \\
-0.0- \\
(\mathbf{0 . 0 0 \% )})\end{array}$ & $\begin{array}{c}\text { INF } \\
-0.6- \\
(\mathbf{0 . 3 6 \% )}\end{array}$ & $\begin{array}{c}\text { INF } \\
-1.2- \\
(\mathbf{0 . 5 2 \% )}\end{array}$ \\
\hline
\end{tabular}


Table 6a. Model Rankings using Asymmetric Linear Tick Loss Function - Before GFC

\begin{tabular}{|c|c|c|c|c|c|c|c|c|c|}
\hline & CAC & DAX & DJ & FTSE & HSHK & IBEX & NIKEEI & SMI & SP500 \\
\hline & EGARCH_T & EGARCH & EGARCH & INF & INF & EGARCH_T & GJR & EGARCH_T & GJR \\
\hline & INF & EGARCH_G & EGARCH_G & EGARCH_T & MEDIAN & GJR & EGARCH_G & EGARCH_G & MEAN \\
\hline & EGARCH_G & EGARCH_T & GJR & EGARCH_G & SUP & GJR_G & GJR_G & EGARCH & EGARCH \\
\hline & EGARCH & MEAN & MEDIAN & EGARCH & MEAN & GJR_T & MEDIAN & INF & MEDIAN \\
\hline & MEAN & GJR_T & MEAN & GJR_T & RSKM & MEDIAN & EGARCH_T & GJR_T & EGARCH_G \\
\hline & GJR_G & GJR_G & GJR_G & GJR_G & GJR_T & EGARCH_G & MEAN & GJR_G & GARCH_G \\
\hline$\dddot{0}$ & GJR & MEDIAN & EGARCH_T & MEAN & EGARCH & MEAN & GJR_T & MEDIAN & GJR_G \\
\hline एँ & MEDIAN & GJR & GARCH_T & MEDIAN & GARCH & INF & INF & MEAN & GARCH_T \\
\hline & GJR_T & INF & GJR_T & GJR & GJR & EGARCH & GARCH_G & GJR_N & EGARCH_T \\
\hline & GARCH_G & GARCH_T & GARCH_G & GARCH_T & GARCH_G & GARCH & GARCH & GARCH_T & GJR_T \\
\hline & SUP & GARCH_G & SUP & RSKM & EGARCH_G & GARCH_G & GARCH_T & GARCH_G & RSKM \\
\hline & GARCH & GARCH & RSKM & GARCH_G & EGARCH_T & RSKM & RSKM & RSKM & SUP \\
\hline & RSKM & SUP & INF & GARCH & GJR_G & GARCH_T & SUP & SUP & INF \\
\hline & GARCH_T & RSKM & GARCH & SUP & GARCH_T & SUP & EGARCH & GARCH & GARCH \\
\hline
\end{tabular}


Table 6b. Model Rankings using Asymmetric Linear Tick Loss Function - During GFC

\begin{tabular}{ccccccccc} 
CAC & DAX & DJ100 & FTSE & HSHK & IBEX & NIKEEI & SMI & SP500 \\
\hline GARCH_G & EGARCH_T & GARCH_G & INF & EGARCH_G EGARCH_T & EGARCH_T & INF & MEAN \\
EGARCH_T EGARCH_G & MEAN & EGARCH_T & GJR_G & MEDIAN & GJR_G & EGARCH_T EGARCH_T \\
GARCH_T & MEDIAN & MEDIAN & GARCH_T & MEAN & MEAN & GJR_T & GARCH_T & MEDIAN \\
RSKM & MEAN & GJR_G & GJR_T & EGARCH_T & GARCH_G & INF & GJR_T & GJR_G \\
MEAN & GARCH_T & GARCH_T & MEAN & MEDIAN & GJR_T & MEDIAN & GARCH_G & GARCH_G \\
INF & GJR_T & EGARCH_T & MEDIAN & EGARCH & EGARCH_G & GJR & MEAN & GARCH_T \\
MEDIAN & EGARCH & GJR_T & GARCH_G & GJR_T & GARCH & MEAN & EGARCH_G & GJR \\
EGARCH & GARCH_G & EGARCH_G & GJR_G & GJR & GJR_G & EGARCH_G & MEDIAN & GJR_T \\
GARCH & GJR_G & GJR & EGARCH_G & GARCH_G & GARCH_T & GARCH_T & GJR_G & INF \\
GJR_T & GARCH & INF & GARCH & SUP & INF & GARCH_G & EGARCH & RSKM \\
GJR_G & INF & RSKM & RSKM & GARCH_T & RSKM & GARCH & GARCH & EGARCH_G \\
GJR & RSKM & GARCH & GJR & INF & GJR & EGARCH & GJR & GARCH \\
EGARCH_G & GJR & EGARCH & EGARCH & GARCH & EGARCH & RSKM & RSKM & EGARCH \\
SUP & SUP & SUP & SUP & RSKM & SUP & SUP & SUP & SUP \\
\hline
\end{tabular}


Table 6c. Model Rankings using Asymmetric Linear Tick Loss Function - After GFC

\begin{tabular}{|c|c|c|c|c|c|c|c|c|c|}
\hline & CAC & DAX & DJ100 & FTSE & HSHK & IBEX & NIKKEI & SMI & SP500 \\
\hline \multirow{14}{*}{$\frac{\grave{ \pm}}{4}$} & MEAN & RSKM & GJR_T & MEAN & EGARCH & EGARCH_T & MEDIAN & EGARCH_ & GGJR_T \\
\hline & MEDIAN & GARCH_G & GJR_G & MEDIAN & GJR & GJR_T & MEAN & EGARCH & MEDIAN \\
\hline & GJR_T & GARCH_T & $\mathrm{EGARCH}_{-}$ & EGARCH_T & SUP & GJR_G & GJR_G & MEDIAN & GJR_G \\
\hline & GJR_D & INF & MEAN & EGARCH_C & $\mathrm{G} A \mathrm{ARCH}$ & MEAN & EGARCH_C & G MEAN & MEAN \\
\hline & EGARCH_ & GARCH & MEDIAN & GARCH_G & RSKM & MEDIAN & GARCH & ${ }^{\mathrm{EGARCH}}$ - & TEGARCH_T \\
\hline & EGARCH_ & MEAN & EGARCH_ & ̧ RSKM & GJR_G & EGARCH_G & G GARCH_G & GJR_G & GARCH_G \\
\hline & GJR & MEDIAN & GARCH_G & $\mathrm{GARCH}$ & EGARCH_C & IINF & $\mathrm{EGARCH}$ & GJR_T & GARCH_T \\
\hline & GARCH_D & GJR_T & GJR & GJR_T & MEDIAN & GJR & GJR_T & GJR & GARCH \\
\hline & GARCH_T & EGARCH_T & $\mathrm{GARCH}$ & GARCH_T & MEAN & GARCH_G & RSKM & GARCH_G & INF \\
\hline & EGARCH & GJR_G & GARCH_T & GJR_G & GARCH_G & GARCH_T & EGARCH _ & T GARCH & GJR \\
\hline & INF & EGARCH_C & INF & EGARCH & GJR_T & GARCH & GJR & RSKM & EGARCH_G \\
\hline & GARCH & GJR & RSKM & INF & EGARCH_T & RSKM & SUP & SUP & RSKM \\
\hline & RSKM & EGARCH & EGARCH & GJR & $\mathrm{GARCH}_{-} \mathrm{T}$ & EGARCH & $\mathrm{GARCH}_{-} \mathrm{T}$ & $\mathrm{GARCH}_{-} \mathrm{T}$ & EGARCH \\
\hline & SUP & SUP & SUP & SUP & INF & SUP & INF & INF & SUP \\
\hline
\end{tabular}

